UC-NRLF

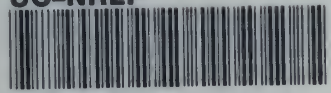

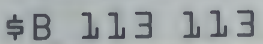




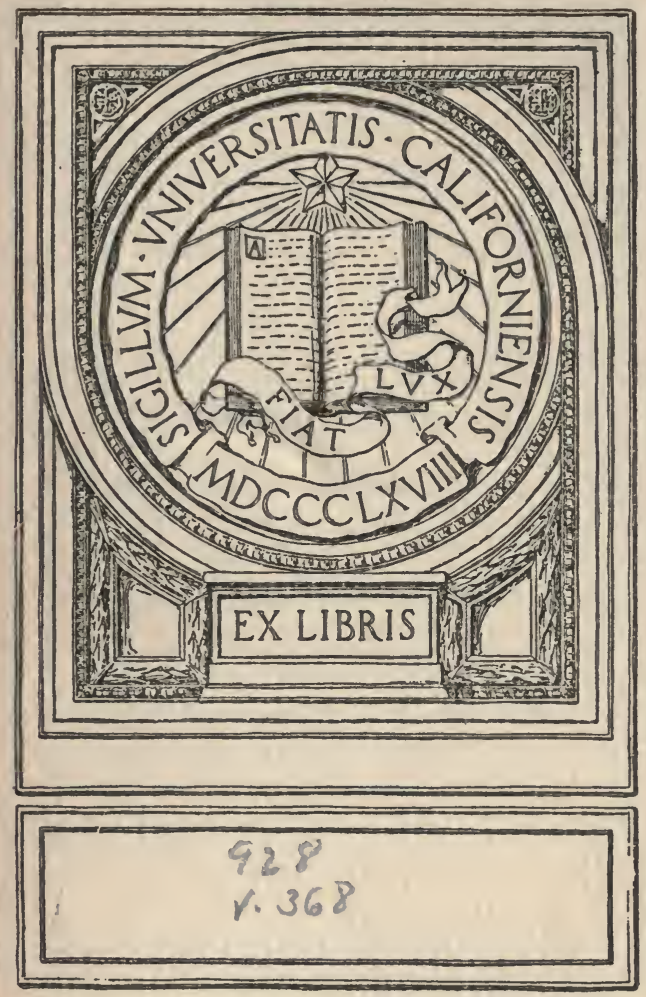



Digitized by the Internet Archive in 2007 with funding from Microsoft Corporation 




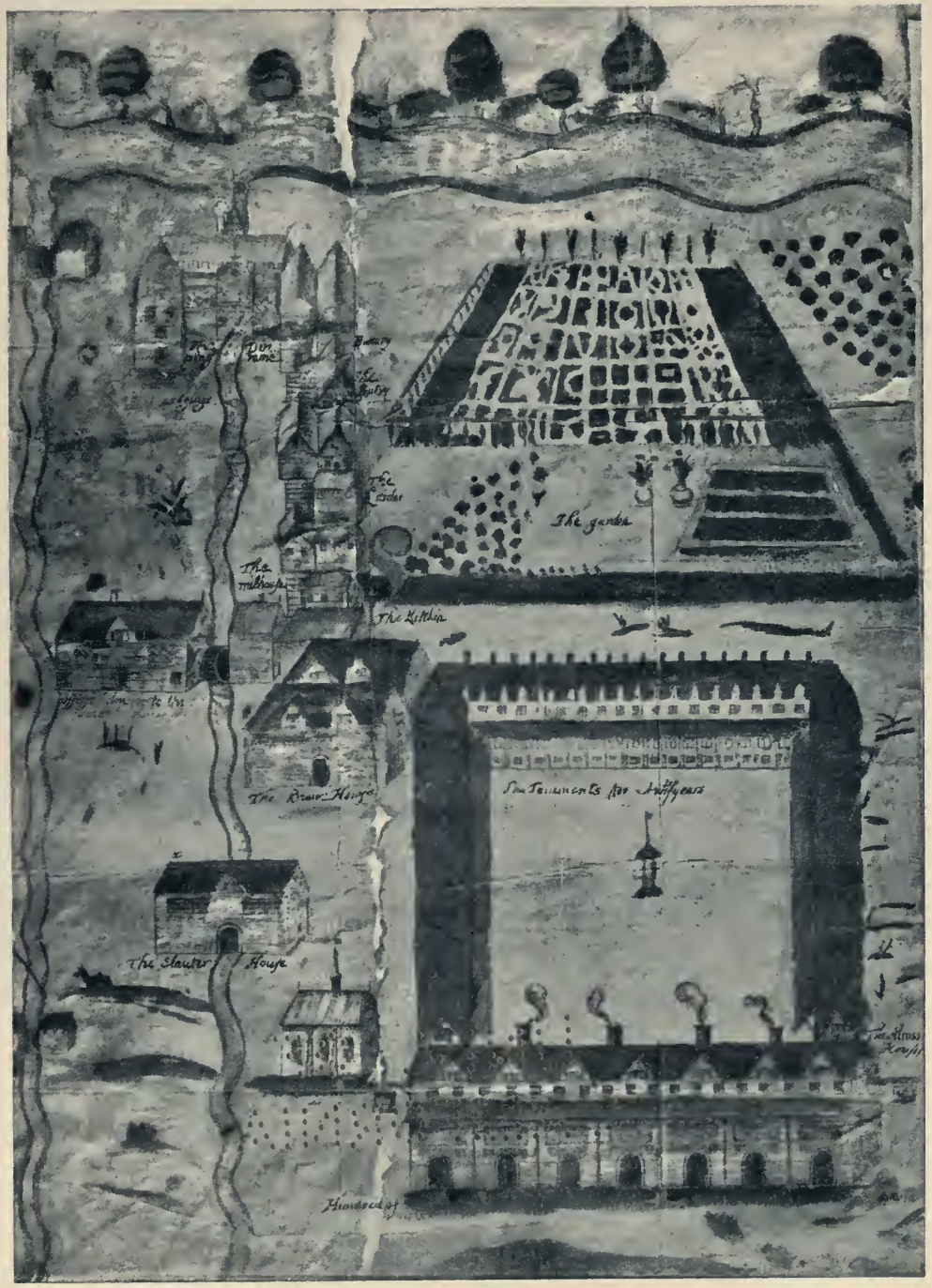




\section{Rowland Vaughan}

. His Booke .

Tav

\section{Published I6ro}

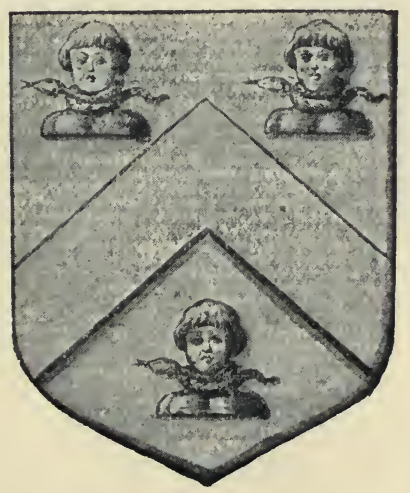

Republished and Prefaced by

Ellen Beatrice Wood, 897

\section{John Hodges}

39 Bedford Street, Strand, London 


$$
\begin{aligned}
& 928 \\
& \sqrt{3} 6^{8}
\end{aligned}
$$

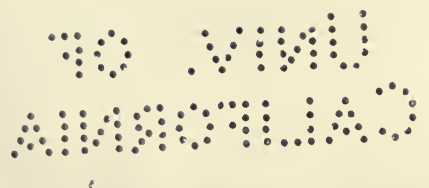

Printed by Ballantyne, Hanson \& Co. At the Ballantyne Press 


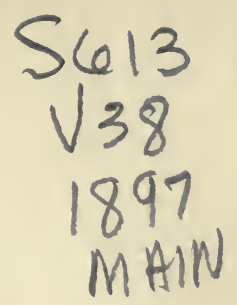

"Whoever could make two ears of corn or two blades of grass to grow upon a spot of ground where only one grew before, would deserve better of mankind, and do more essential service to his country, than the whole race of politicians put together."

-SWIFT. 

The extreme quaintness and originality of Rowland Vaughan's little book have led me to republish it, in the hopes that what has charmed me in its diction, will not prove "caviar to the general." The spelling and punctuation I have scrupulously followed, but have omitted the old-fashioned lettering. The original binding was too costly for reproduction, so I have taken a suggestion from $i t$, with a view to keeping up the character of the book.

I cannot write even a small half-page of introduction without acknowledging my indebtedness to Dr. Vevers, who, by kindly lending me his copy of the "Water-workes," halved my labours by enabling me to transcribe it at home; and to Mr. J. H. Parry of Harewood, from whose hospitable house I 
pilgrimaged to see New Court and the Golden Valley, and who has done one or two pilgrimages since, in order to verify my information, or to dig deeper into the subject for me. To those two gentlemen the " hearty thanks of mee," who remain " theirs, as they have given mee cause,"

\section{ELLEN BEATRICE WOOD.}

Molewood House, Hertford,

November 1896. 


\section{INTRODUCTION}

OF Rowland Vaughan, author of the following pamphlet, so little is known, except what he himself tells us, that an introductory sketch of even a few pages is a matter of some difficulty. The second son of Watkyn Vaughan of Bredwardyne, County Hereford, he was intended for Court life, his first-cousin, Rowland Vaughan of Porthamel (afterwards M.P. for Breconshire), being Groom of the Chambers to Queen Elizabeth, and his grand-aunt, Dame Blanche Parry, her great friend and chief Bedchamber-woman; but, as he himself tells us, "his spirit was too tender to endure the bitternesse" of Dame Blanche's "humor," and after some years spent in the greatness and glory of Court, he was "forced" by the same old relative's "careful, though crabbed, authority" into the Irish wars - probably 


\section{INTRODUCTION}

those of Sir Henry Sidney against the O'Desmond.

Here he spent three or four years; but this time it was his body that was "too tender," and the standing waist (or, to use his own expression, "twist") deep in the bogs, combined with fasting and ill diet, sent him home invalided to Bredwardine.

That Bredwardine was a place of some pretensions, we learn from some seventeenthcentury manuscript notes for a History of Herefordshire. First in a list headed "Where appeare any tokins of great old houses now done desolated" we find "Castells within the shire on the south side of Wye-the Castel of Bredwardine." Then in an account of the different parishes comes, "Bredwardine had a faire castel called the Castel of Grone, and another at the place called the Court of Vaughans, called also the Radnor; the first held by appearing at Brecknocke Castle gate on horseback completely armed with his speare, and there to wait all day on the day of It is now honoured with a family of the Vaughans, of the second house, whose ancestors by a match with one of the co-heirs of the Parrys had by her great viii 


\section{INTRODUCTION}

revenues." This alludes to the marriage of Rowland's father, Watkyn, with Joan Parry, daughter of Henry Parry of New Court.

The manuscript goes on to state that in Bredwardine Church is an effigy of a knight in full armour, supposed to be "by tradition, and that probable," John de Bredwardyne, knighted by William the Conqueror.

Thus far goes the Harleian M.S. No. 6868. M.S. No. 6726, also Harleian, written in I 655, tells us a little more about Bredwardine. It states, "The dwelling-house, very fairly built by Roger Vaughan about the year I639I640, was an ancient and strong castle, retaining that title still. It was called anciently the Castel of Grone; the lands and tenements belonging to it is still called by the name of the Manor of Grone. Another Lordship in this parish, which is held by the suit and doome in the County Court, and belongs unto the Vaughans, is called the Court of Vaughans (belonging to another branch of Vaughans, viz., Sir George Vaughan), was sold to those Vaughans of Bredwardine about the year 1630. There is a small fortified hill, which was for the safeguard of the inhabitants against sudden invasion." 


\section{INTRODUCTION}

In Rowland's day, then, the place was a "faire castell." The rebuilding of I640 was not till after his death, Roger being his nephew, son to his elder brother Henry Vaughan of Moccas; but two years even in this "great old house" bored our hero to such an extent, that he would have gone off again to the wars, had not his fair kinswoman, Elizabeth Vaughan, intervened, and turned his thoughts towards matrimony.

Elizabeth was daughter of the abovenamed Rowland of Porthamel and Elizabeth Parry of New Court, co-heiress with her sister Joan, who married Rowland's father, Watkyn of Bredwardine, of the New Court estates.

The Parrys and Vaughans intermarried in each generation, and the cross-relationships are so puzzling, that I shall not attempt here to follow up the pedigree of either family, except to draw attention to the fact that they were both very proud of their kinship with David Gam, the hero of Agincourt, from whose daughter, "Gladis de Gam," sprang the Vaughans by her first marriage with Sir Roger Vaughan, who was killed at Agincourt, and the Pembrokes by a second marriage with Sir William Herbert, father by her of the first 


\section{INTRODUCTION}

Earl of Pembroke. The Vaughans and Pembrokes fought side by side in many a fight, and the dedication of Rowland's book to the then Earl show that the feeling of kinship had survived the wear and tear of nearly two hundred years.

Rowland Vaughan of Porthamel and his wife, Elizabeth Parry, had two daughters (their son died unmarried in 1582), Elizabeth, who married our hero, and Katherine, who married Sir Robert Knollys, and so became daughter-in-law to dear old Sir Francis Knollys, whose wife, Katherine Carey, was Queen Elizabeth's first-cousin.

The fair and virtuous Elizabeth Vaughan was "a loving wife," according to her husband, but apparently one who would stand no nonsense. She soon put a stop to his roystering with old comrades, and bade him employ himself at home, by looking after her property, she "being seized of a mannor and overshott mill." The manor was New Court. An apparent disagreeable with the miller made Rowland wish to get rid of his responsibility, but madam overruled him, and he "obeyed her will, as many doe, and many miseries do ensue thereby." And so, "in the 


\section{INTRODUCTION}

month of March," our Rowland ("with no desire, I protest, to fashion or forme husbandry") was wandering by the mill-stream, possibly whistling as he went for want of thought, or thinking regretfully of those boon companions, only now allowed to memory, when his wandering eye fell upon a small stream, or, as he would call it, a "waterprill," issuing from a molehill, and from this small beginning came his mighty scheme of irrigation. His difficulties were great. His neighbour, Rowland Parry of Moorhampton (whose son Stephen afterwards became our Rowland's son-in-law), readily gave him permission to make the necessary uses of his side of the river; but one of his tenants ("being very aged and simple") made such a to-do, that, after Rowland had vainly tried what he calls "bugg words," bribery had to be resorted to, with the result that the simple(?) rustic got a "meadow-plott" worth $£ 40$, instead of the three acres of old meadow-land, heavily laden with moss, rush, and cowslip, which his landlord so much coveted. Of the money spent we can form no estimate. Over one piece of trenching (which, the neighbours said, would cost a thousand marks) Rowland 


\section{INTRODUCTION}

saved a $£$ roo by his crafty way of setting to work. Elsewhere he mentions that a bad piece of work on the part of a vain-glorious carpenter cost him over $£ 2000$. But his book must have bitterly disappointed any one who tried to get real practical information on either of his subjects; his wandering mind flies off anywhere, wholly irrelevant anecdotes are begun and never finished, and real statistics are the last things he would condescend to work out for us. Still, he states that his demesne at New Court was let for $£ 40$ a year, and "is now worth $£ 300$ " ; that one meadow, for which he got $£ 5$ yearly, now yields $£$ I 5 in hay and aftermath alone; that if at the end of four years' "drownings" your outlay of $£ 500$ has not made itself $£ 2000$ or $£ 3000$, "your choyce" (of land) "is bad, and luck worse." He offered a neighbour $£$ I 5 a year for a hundred acres of arable (that being its rental) on a four years' agreement, at the end of which time Rowland was to have a twenty-one years' lease of it at $£$ Ioo a year, all cost of putting up sluices, \&c., to be Rowland's; but on the entering of the twenty-one years' lease the neighbour was to put down $£ 300$, which, xiii 


\section{INTRODUCTION}

as Rowland observes; he gets back in three years.

Though the hundred acres was "in the eye of his house," and must have been unsightly in its state of unculture, the neighbour refused the offer. "He offered nothing, and he hath done nothing," says Rowland, "therefore this is but an accusation for negligence, setting it forth in as friendly a manner as I may."

Further on we learn that three moles, suffered to live by a servant's carelessness, cost him $£ 20$ a year in damage to the "stankes," and there is an amusing little homily on the sin of ingratitude to these little creatures, who were the originators of all the vast system of irrigation; but though they are offered the run of his pleasaunce, burrowing in the "Stanke Royal" is high treason, and the moles are doomed, in spite of qualms of conscience.

Then, too, the saving of labour is slightly touched on, but these facts are scattered all about the book, and one can only guess that the cost must have been immense, though Rowland blames his neighbours for not following his example, in utter oblivion of the fact that they may not have had any capital to advance, as not to every one's share falls a xiv 


\section{INTRODUCTION}

wife seized of a "mannor and a overshott mill."

And here I must note that a mill in those days was apparently a very choice possession, for Rowland thus comments on their owners : "The mill may be worth four or five pound; but because he will win reputation to his demesnes on information on the marriage of his son that he hath such a mill, he would rather suffer muddy flouds in winter and clean water in summer to breake their limbs in his mill-wheels then exercise his wits (by drowning) to attain a world of wealth."

When or why Rowland first thought of the project which he calls his "common-wealth" does not appear, but it also must have been a gigantic work; we gather it was begun after the completion of the water-works, as he says, "I have built my mill, and acquainted the water with his course; unto this mill I add all offices," \&c., \&c. This commonwealth was a sort of community of tradesmen, who supplied each other with their specialties before offering them in open market; a clerk fixed the rate at which the tanners was to supply the glovers, and the carders the spin- 


\section{INTRODUCTION}

ners, \&c.; and justice seems to have been meted out with a steady hand. Great order was kept in the commonwealth; a first offence was reprimanded, a second punished, the third entailed banishment from the precincts.

Rowland thus got a market for all his farm produce. He grew the sheep and kine which both fed and employed his glovers and weavers, the tanners got their bark from his forests, and he seems to have personally superintended everything. A great number of the operatives were housed on the premises; and we read of their washing-places, their eatinghall, their hospital-indeed, of every convenience that human ingenuity of those days could dream of.

Two thousand "mechanicalls" had joined Rowland's community by the time of his writing his book (I604), which was in those days a very much larger number proportionately to the population than it is now, especially in that remote corner of England or Wales, as Rowland repeatedly calls Herefordshire These two thousand workmen daily assembled to food in the big hall at sound of trumpet; but bodily food was not the only thing supplied for them by their energetic xvi 


\section{INTRODUCTION}

"protector." He built them a chapel, attended by both preacher and curate, who got respectively $£ 50$ and $£ 20$ yearly-good stipends for those days-and almshouses for the sick and old. The priests must have been a great boon outside the commonwealth, for in all the Golden Valley, " which is seven miles long and one broad," there was not one parish which could afford to maintain a priest, and a young "preacher" used to come over from Hereford every now and then, and preach so many sermons at so much a piece, charging very high, Rowland hints, on account of the fancied perils of the journey!

Other ministrations the people had none, except that of an old monk, survivor of the "great house of White Monks" (Abbey Dor), who is evidently in Rowland's eyes a great deal worse than nobody; though I cannot decide whether a Papist or a Puritan was his chiefest aversion - probably the latter, the religion which did not allow oaths being quite unfit for any gentleman.

The poet, John Davies of Hereford, who lauds his kinsman with such fervour that only the knowledge that he was writingmaster to Henry Prince of Wales, and a xvii 
great celebrity in his own line (Fuller says his handwriting was so beautiful that one had to examine it under a magnifier to see if it were print or no), prevents one thinking that he was largely in Rowland's debt, says that "the Mechanicalls" all wore "scarlet capps," and filled their chapps and lapps from the forty dishes, which we learn were daily provided for them. This scarlet Rowland also alludes to, saying that if he did go again to Court he would be but a shabby figure, though smart in a sense, as wearing "scarlett of Builth, or Welch frize."

It was twenty years from the time of that walk, one day in March, before the account of the water-works was begun-and that apparently took about six years to write, as he notes events taking place as he writes in 1604, and the date of publication is 1610 . That he dictated it is evident, from the words "take breath" written in by error on the part of the secretary at the close of a sentence.

While the "Water-works" were in progress old Dame Blanche died (in 1589). She left Rowland $£ \mathrm{IOO}$, a most handsome bequest in those times, and also $£^{20}$ for the repair of the road between "Moat and Douro, and New xviii 


\section{INTRODUCTION}

Court and Moorhampton." Douro sounds so suggestive of Spanish settlers that I must quote what my MS. says about it: "The vale of Straddel is that which we call the Golden Valley-ystrad in Welsh is valleyand we may believe this is the most ancient denomination of it, for dyffrin dwr being sounded among the Normands, they thought they had heard the word d'or, and so Englished it the Golden Valley, whereas the latter Welsh denomination signifies noe more than the Watry Valley."

Thus my manuscript; but another legend has it that when the Saxon invaders pushed the Welsh back into "Welsh Wales," they asked some captive the name of the little brook which runs purling through the valley, and were told Dwr, which means simply water, but which they caught up as Dor, and hereafter called the river "the Dor." In later days the monks, moved either by the fairness of the landscape or the golden richness of the fields ripe for harvest, perpetrated a monkly jest, and called the valley Valle d'Oro, the Golden Valley, or the Valley of the Dor. However that may be, in Rowland's time it was always called the Golden Valley, xix 


\section{INTRODUCTION}

but the great ruined abbey at the mouth of it was known as Abbey Dor or Douro, and it is then between the abbey and Moat that the road was to be kept up. Immediately after the Reformation, John Scudamore, of Kent Church, had interposed to stop the work of desecration and spoliation of the abbey, and turned part of it into an Anglican place of worship, and I suppose it is to him alone we owe the partial preservation of it-all honour to his name!

From I 584 to I 600 Rowland was involved in one lawsuit after another. They are extremely dull lawsuits, their only interest being that they show what large possessions Rowland had acquired, either by inheritance, money-lending, or purchase. The suit in I 584 is against one Dame Anne Gresham, with regard to some property which Rowland owns by right of his wife, who inherited from her brother William, who died childless in I 582 .

Then in I 596 is one against James Parry of Poston, who seeks to "redeem tithes within the townships of Poterchurch, Hynton, Taylorshope, Wilbroke, Leynalls, and Wylawstone, in the parish of Peterchurch, which he $\mathrm{xx}$ 


\section{INTRODUCTION}

held in lease for years, and the park of Snodhill, his inheritance, which he mortgaged." Rowland had lent James Parry $£ 20$ on the security of the abovenamed tithes.

Then comes a Star-Chamber case, and then, crowning misfortune, one in the "Court of Wardes," which, as Rowland pathetically says, "Bredd more white haires in my head in one yeare then all my wetshod water-works in sixteene." This case lasted five years, and during its course Rowland went home to see to his "drownings" (sadly neglected, we hear, during his absence), leaving his "Wanton Warde," as he calls her, in charge of a Puritan tailor, and the next thing he hears is that his "Welsh niece," alias the Wanton Warde, has married the tailor's nephew.

Rowland's wrath knows no bounds; he has a stormy interview with the tailor, who declares his ignorance of the intrigue; but when Rowland wants him to swear on the cross of his shears, he refuses, it being against his principles to swear. It is not, however, against Rowland's, and black surmises about complicity are made, and our poor old squire loses all chance of the customary "tip" over that ward's marriage, and is not that enough

$$
\mathrm{xxi}
$$




\section{INTRODUCTION}

of itself to "brede white hairs in a Brittaines beard?"

In I 594 Rowland's sister, "Lady Gattes," died; and as her funeral certificate is rather quaint, I append it; it is from the collection at the College of Arms.

"Catherine, Lady Gattes, doughter to Watkyn Vaughan of Bredwardyn, in Cōm. Hereford, Esquire, had in her lyffe time three husbands, the first James Boyle of Hereford Towne, Esq., and by him had two doughters. Anne, $I^{\circ}$ doughter, and one of $\hat{t}$ heirs of James, was marryed to James Tompkyns of Monnington, in Cōm. Hereford, Gent. Marye, second doughter, and one of $\mathrm{t}$ heirs of James, was marryed to Howell Gywnne of Trecastle, Cō̄. , Esq.

"After, the aforenamed lady marryed her second husband, Sir Henry Gatte of Senne, in Com. Yorke, Knight, but had no yssue. Thirdlye, and lastly, she marryed Robert Whytt of Aldershott, in $\mathrm{Co} \bar{m}$. Southe, Esquire, but had no yssue. Thys lady departed this lyffe to the Lord the I 5 November at Westmynster (in the gat house erased), and was buried in St. Margarettes Church there, the wone-andtwentyeth, of the moneth aforesaid, I594. xxii 


\section{INTRODUCTION}

Chefe moorrner at her funerall the Lady Hawkyns, and there servyd Clarencieux, Kinge at Armes and Blew Mantle. In witness whereof I have sett hereunto my hand the day and yere abowsaid."

In I609 we find Rowland joining with his son John in the sale of the manor and lands of Wormebridge, in Turneston parish. This property Rowland had bought from Sir Christopher Hatton, who had received it as a grant from Queen Elizabeth. After one intermediate generation this property passed into the hands of the Clives of Styche (in Shropshire), who in I 800 bought out some descendants of the New Court Parrys, who still had Wormebridge place, and pulled down both houses, building in their stead their present seat of Whitfield.

The last page of Rowland's book contains a formal acknowledgment of a debt of forty shillings. Of the four copies to which I have had access, only three have the acknowledgment, and only one has any name filled in. The name has been carefully erased, not so carefully, however, but that we fancy we can decipher it as William Powell, in the parish of Llywell, in the county of Brecknock, xxiii 


\section{INTRODUCTION}

the last word being quite clear. It runs thus :

"Be it known unto all men by these presents, that I, Rowland Vaughan of New Court, in the County of Hereford, Esquire, do acknowledge myselfe to owe and stand duly indebted unto

, in the County of

, the sum of 40 shillings of lawfull money of England, to be paid unto the said

, his heirs, executors, or administrators, at the full end and determination of five years next ensuing the date thereof. To the which paiement will and truly to be made, I, the said Rowland Vaughan, doe binde mee, mine heires, executors, and administrators, firmly, by these presents. In witnesse thereof I have caused this Bill, thus in print, to bee made as my Deed, and have hereunto set my name the XxIx of November, in the yeare of the raigne of our soveraigne Lord James, by the grace of God of England, France, and Ireland, King, defender of the Faith, the VII. and of Scotland the XLIII. I6o9.

"By mee, Rowland Vaughan."

One copy of the book, in the British Museum, has manuscript notes in a sevenxxiv 
teenth-century hand, calling attention to various statements, making Chaucer the author of the old saw, "Thou art an old doting fool," and stating that Rowland's promise of further explaining his use of the levell by a picture, or, as he calls it, a mapp, has not been fulfilled.

Gough, in his "Typographica Brittanica," mentions two maps, but I have only been able to reproduce one, from a photograph off an engraving in Duncombe's copy of the work, which engraving was discovered by Dr. Vevers of Hereford in I883. It should be somewhere about the centre of the book; but I have, for various reasons, put it in the place of the missing frontispiece.

The two main ostensible reasons for the book, namely, the irrigation scheme, and the commonwealth or community of trades, do not by any means sum up Rowland's resources. He must have had great mechanical skill, as he used his water-power for all sorts of purposes, amongst others for turning his kitchen spits (at the factory, not at home), and sawing timber. He soon discovered the cheapness of water traffic, and built a boat to convey his farm produce from the White House to New 


\section{INTRODUCTION}

Court, where the "Mechanicalls" had their headquarters; whilst his remarks on the breeding and rearing of calves, though they savour somewhat of the kindergarten system of education (teaching by playing), show that he took great heed to his stock as well as his crop. I cannot find if any of his neighbours followed his example; for, though my manuscript tells of the remains of trenches at Moccas, where his brother Henry lived, one can only conjecture that they might possibly have been for irrigation purposes, and I have searched in vain for any remark in the histories of Shropshire about that ill-judged attempt of Maister Hoord, of which Rowland speaks in his book.

The date of Rowland's death and his age are unknown. I can find neither will, inquisition, nor certificate; but on a beam in Peterchurch Church is the Vaughan coat-ofarms, quartered with that of Gams (?), with date I6I2, the last figure somewhat doubtful, which I take to be a monument to the old man. The blazon of the Vaughan coat, which is reproduced on the title-page, is-Sable a chevron argent between three boys' heads affrontée, couped at the shoulder proper, xxvi 


\section{INTRODUCTION}

crined or, and about each neck a serpent entwined vert. This coat was adopted on account of the legend that Moredig Warwyn, one of their ancestors, was born with a snake round his neck. The Bredwardine Vaughans always bore the chevron, as appears in the visitation of Herefordshire of 1619 , from which the York herald has copied this coat for me.

There is a legend that our Rowland is buried at West Ham, but there are no registers there prior to 1653 , and there is no trace of a tomb; but I found the inquisition of a certain Rowland Vaughan, a city knight, who died in I6I2, and I consider he was probably buried in the old church, not our Herefordshire Rowland; the fact that this city man had also a wife Elizabeth, and left no male heir, is quite enough to account for the story.

Elizabeth Vaughan re-married a certain Richard Leighton, and is buried at Vowchurch. The date on the tomb is 1640 , but it is so rudely cut that it may have been added later, and be quite incorrect. The inscription runs thus: "I. H. S. Here lieth the body of Eliza Leighton, wife to Richard xxvii 


\section{INTRODUCTION}

Leigh, and formerly married to Rowland Vaughan, Esquire, deceased."

Rowland had three children. One son, John, who died sans issue, I believe, before his father-he was alive and of age in 1609and two daughters. Jane, who had New Court, married her kinsman, Stephen Parry of Moorhampton, who exchanged the combined properties for that of Arkeston, in the parish of Kingston, Co. Hereford. Blanche married Epiphany Haworth, and had the White House, where her father had always lived. This was occupied by descendants of hers till about fifty years ago, when it changed hands. Some chairs, which had belonged to Queen Elizabeth, and which she is said to have given to Henry Parry of New Court, Rowland's grandfather; and a portrait of a lady in Welsh dress, bearing inscription, "Blanche Parry, I 590," were bought at the sale by, and still belong to, Dr. Jenkins of the Copelands, Hereford. As to the original of the portrait, the greatest authorities disagree. It was long thought to be the celebrated lady of the Bedchamber, but as she died very old, and blind, in 1589, that is impossible. Mr. Parry of Harewood conxxviii 


\section{INTRODUCTION}

siders it to have been Blanche Haworth herself, though I cannot see why it should then be called Blanche Parry. I think it is of her sister's mother-in-law, who was Blanche Parry both as maid and wife, though I own I cannot account for its presence at the White House, unless Jane and Stephen did not care to move it with them to Arkeston.

Herefordshire is singularly unlucky in its county history. Duncombe, who was writing one to order, was not public-spirited enough to continue his work on the death of his patron; and though other hands have continued his work with the help of his notes, the Hundred of Webtree is altogether omitted, while the Hundred of Ewyas is very sketchily done, and contains no mention of Rowland or his works. That they were the sight and talk of the neighbourhood, is evident from the fact that open table was kept for visitors to the commonwealth, whose coming was notified by a watchman by beat of drum or blair of trumpet, according to the condition of the approaching guest, "whether he be horseman or footman."

In 180 I Mrs. Burton, the wife of the then vicar of Atcham, in Shropshire, and herself 


\section{INTRODUCTION}

one of the Parry family, pilgrimaged to Bacton and New Court, and describes the latter place as being a dreary, ruinous farmhouse. It had once been moated, according to the custom of our ancestors. In two of the rooms, which seemed to have been bedrooms, were remains of carved oak wainscotting, and an old carved staircase betrayed evident traces of the splendours of past times. An upper room had been curiously painted, some of the figures yet remaining on the walls. The ceiling appeared to have been arched; the Gothic window remained to determine the architectural character of the old mansion. Mrs. Burton speaks with enthusiasm of a magnificent variegated oak, and describes the remains of the terraced gardens, with its ruined summer-house. The old farmhouse was replaced by a modern building shortly after this visit; and New Court and Moorhampton are now farmhouses of the most ordinary (I mean commonplace) description.

The absolute disappearance of all traces of Rowland's irrigation works, and of the great buildings necessary for the housing and employing of his community, can only be attributed, to the civil wars, which raged 


\section{INTRODUCTION}

with great fury in Herefordshire, a most obstinate stronghold of the Royalists. What side the Vaughan's took, I know not; the Parry's were stout Roundheads.

The fact, too, that Rowland's son-in-law exchanged properties with another branch of the Parrys, thus bringing New Court into the hands of those who had no personal interest in his experiments, may have begun the end which the civil wars undoubtedly finished; but we can have little doubt that 2000 "Mechanicalls" could not be allowed to spin and weave when stout men were wanted for the fight, and who knows but that these members of the "Common-wealth" were all the more acceptable from the discipline they had already gone through under our Rowland. I must hope that they helped the cause of the son of their "deare master," who is spoken of with such affectionate respect, and considered the embodiment of human virtues, not that of the Puritan, who would no more have sworn on the cross of his sword than would that "tailour," who behaved so "scurvily," upon his shears, and whose whole conduct would have filled Rowland with deep disgust.

$$
\text { xxxi }
$$




\section{INTRODUCTION}

The absence of all outside accounts of Rowland's works make a more complete sketch of his life impossible, and our imagination alone can fill in the blanks. We must, then, fancy the old squire in his scarlet cape, riding-rod in hand, walking down the Golden Valley from the White House to New Court (some three miles) to overlook the raising of the sluices and the marshalling of his "Mechanicalls" to dinner, or, as one can well fancy, reading the Riot Act to the unruly, and intermeddling with kindly officiousness in the private matters of his people. Or in later days, too old now for the walk down and up the valley, dictating his " Long experienced Water-workes" to his admiring amanuensis, interrupted now and then by his masterful helpmate or his dearly loved children; and so slips the time away, till first the book and then the life draws to an end, and Rowland Vaughan sleeps with his fathers, and of him all that remains to us is this little pamphlet. 


\title{
MOST APPROVED,
}

\author{
And
}

Long experienced WATERW O R K E S.

Containing,

The manner of Winter and Summerdrowning of Medow and Pasture, by the advantage of the least, River, Brooke, Fount, or Waterprill adjacent; there-by to make those grounds (especially if they be drye) more Fertile
Ten for One.

As also a demonstration of a Project, for the great benefit of the Common-wealth generally, but of Hereford-shire especially.

Judicium in melius perplexus cuncta referto, Vera rei, donec sit manifesta fides.

By Rowland Vaughan, Esquire.

Imprinted at London by George ELD. I 6 I 0. 



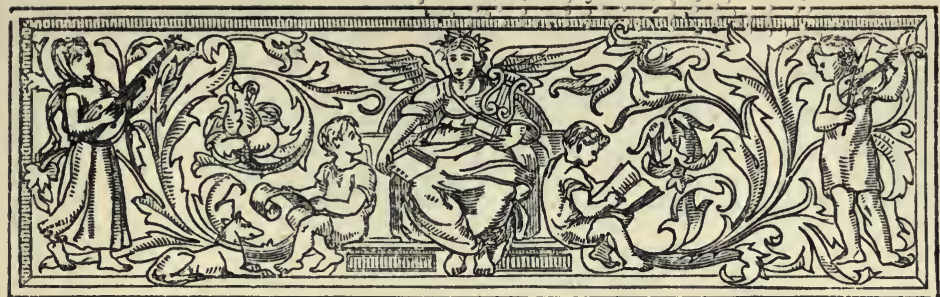

\section{A PANEGYRICKE,}

In the deserved honor of this most profitable worke, and no lesse renowned then much-desired Project.

Ting of him that is as deere to mee

1 As to the World; to whom both aye are bound;

Then briefe, for Bond so long, I cannot be;

Unlesse my Love were (like my Lines) too round.

Proportion doth so please Witte, Will, and Sense,

That where it wants, it grieves Sense, Will, and Witte:

Then by Proportion of his Excellence,

Thus must we shape our praise of Him, and It.

When as the Earth all soild in sinne did lye,

Th' almighties long-provokt inraged-HAND

Emptied Heav'ns Bottles, it to purifie;

And made that (a) FLUD that mud to countermand.

So, for like crimes, of late, we plagu'd have bin

With like (b) O'reflowings, washing all away

That lay the Earth upon, or Earth within,

Within the limitts where this Deluge lay!

(a) Noahs floud.

(b) The Inundation caused by the boiling up of the sea in Munmouth and Glamorgan Which $\begin{aligned} & \text { shire, the } \\ & \text { yeare } 160 \% \text {. }\end{aligned}$ 


\section{$\therefore A$ PA: A E Y Y Y ICKE.}

Which Inundations were for Earth unfit:

But hee whose Hand and Head this WORKE compos'd,

Shewes how to drowne the Earth to profit it:

And beeing Ill, to make it Well-disposd.

Some with their Lands, doe oft so sinck them-selves,

That they to it, and it to them yeeld nought,

But, in the Ocean what doe yeeld the Shelves,

$(a)$ Few Had- Which when they see, they $(a)$ flee, with pensive thought. lands take pleasure to behold the lands they had.

But in His Drownings, He makes Lands arise, In grace and goodnesse to the highest pitch; And Meades, and Pastures price he multiples; (b) Trenches, So, while some lies, He rise doth in the (b) Ditch, by which his workes are effected.

His royall $T R E N C H$ (that all the rest commands And holds the Sperme of Herbage by a Spring) Infuseth in the wombe of sterile Lands, The Liquid seede that makes them Plenty bring.

Here, two of the inferior Elements (Joyning in Coïtu) Water on the Leaze

By equirocation it may bee taken for Infants as wel as Barnes : Barne being the name of Jnfant in some places of England.

(Like Sperme most active in such complements) Begets the full-pancht Foison of Increase:

For, through Earths rifts into her hollow wombe, (Where Nature doth her Twyning-Issue frame) The water soakes, whereof doth kindly come Full-(c)Barnes, to joy the Lords that hold the same : 


\section{A PANEGYRICKE.}

For, as all Womens wombes do barren seeme, That never had societie of Men;

So fertill Grounds we often barren deeme,

Whose Bowells, Water fills not now and then.

Then, Earth and Water, warmed with the Sunne,

Ingenders what doth make Man-kinde ingender:

For Venus quickly will to ruine runne,

If (a) Ceres and her Bacchus not defend her.

(a) Sine

Cerere \&

Bacche,

Then looke how much the Race of Man is worth,

friget Venus.

So much is worth this Arte, maintaining it;

Then ô how deere is hee that brought it forth,

With paine and cost for Man-kinds benefit!

Though present Times (that oft ungratefull proove)

May under-valew both his Worke and Him;

Yet After-times will prize them Price above,

And hold them Durt that doe their glory dim.

For He by Wisedome, over-rules the Fates,

By Witt defeating passions of the Ayre;

When they against his well-fare nurse debates,

While fooles (ore-rul'd by each) die through dispaire.

In dropping Sommers, that do marre the Meads,

His Trenches draine the Raines superfluous Almes;

And when heate wounds the Earth ((b) to death thatbleeds)

Hee cures the chaps with richest Water-balmes.

(b) The

Sunne ex-

haling all

radicall

moysture

from thence

by the

wounds or

chaps which

are made

So by summers

heate. 


\section{A PANEGYRICKE.}

So, when Heav'n (ceaselesse) weepes to see Earths sinne $\mathrm{He}$ can restraine those Teares from hurting him;

(a) The teares of sinners, are the wine of Angels. dominabitur astris. (b) Ars

Untill his Teares the Heav'ns to (a) joy do win, While other Grounds are torne, the life from limbe.

And when the Earth growes Iron, for Hearts so growne, Hee can dissolve it straite (as Waxe it were;) Mantling the Meadowes in their Summer-Gowne; So joyes in hope, while others grieve in feare.

"Thus wisemen ( $b$ ) rule the Starres, as Starres doe fooles; "And each mans manners doe his Fortunes square; "Arte learnes to thrive in Natures practick Schooles; "And Fortune favours men of actions rare.

Such one is this rare Subject of my Rimes, Who raignes by mirry motion, 'ore my Spleene; (c) Or cleare Such is this (c) Water-glasse, wherein these Times Mirrour. Do see how to adorne their Meades in Greene.

Hee from a Mole-hill (from whose hollow wombe (d) From the Issu'd a (d) Water-fount) a Mount did reare; observation A Mount of large Revenues thence did come; ceeded the rest of his workes, as in this his booke more at large is expressed.
So, a Mole-hill great with yong a Mountaine bare!

How many Rivers, Founts, and Water-prills, (Tendring their service to their Lords for Rent) Are nere imployde but in poore Water-mills, While the drye Grounds unto the Bones are brent. 6 


\section{A PANEGYRICKE.}

To Tantalus I can resemble those

That touch the water that they n'ere doe taste;

And pine away, Fruite being at their Nose,

So, in Aboundance, they to nought do waste.

The Brookes runne murmuring by their parched Brincks (Pure virgin Nimphes) and chide against the Stancks, When as their sweetest profer'd service stinkes, So coyly kisse the chapt-lippes of the Bankes.

And (weake as water) in their Beds do stretch (As t'were to yeeld their Ghost for such disgrace) Their Christall limbes unto the utmost Reach; And (a)shrinkefrom th'Armesthat (uselesse) them imbrace. (a) In dry Summers the Rivers grow

When as the Meads, wherein their Beds do lye, lowest.

Make towards them, and fall by lumpes therein ; Who (of the yellow Jaundise like to dye)

Creepe to their ( $b$ ) Beds, their love and health to winne.

O Landlords see, O see great Lords of Land! These sencelesse creatures mov'd to eithers aid But for your helpe, who may their helpes command: Then well command, you shall be well obaid.

Helpe Nature in her Workes, that workes for you ; And be not idle when you may do good:

„Paines are but (c) Sports when earnest gaines insue: "For, Sport, in earnest, lies in Livelihood.

(b) When the Bankes are chapt, they (cleeving) fall by mammocks into the River. (c) Gaines take away the thought 


\section{A PANEGYRICKE.}

The Golden-age is now return'd againe,

Sith Gold's the God that all commands therein ;

By Gold (next God) Kings conquer, rule and raign ;

With Gold we may commute, or grace our sinne.

Briefly, by Him we may do what we will, Although we would do more then well we may:

For He makes ill too good, and good too ill; And more then God, the ill do him obay.

(a) Wealth helps Vertue in her operations; whose hands were else bound from overt action.

(b) All gauly \& too dry grounds rebell against nature, and mens profit.
Then if ye would be eyther Great or Good, Or Good and Great (all which he (a) can you make) Take pleasure (ô) to save your Livings Bloud And streame it through their Limbes, for Profits sake.

This Esculapius of diseased Grounds, (Casting their Water in his Urinalls) (His Trenches) sees what Humor ore-abounds, And cures them straight by Drought or Water-falls.

This little-great-great-little Flash of Witt. This Soule of Action, all compos'd of Flame, (Mounting by Action to high Benefit) Exalts his State, his Countries, and his Fame.

He well deserves to be a Lord of Land, That ore $(b)$ rebellious Lands, thus Lords it well : $O$ that all Lords that can much Land command Would so command it, when it doth rebell. 


\section{A PANEGYRICKE.}

But Pleasure, Pompe, and inter-larded Ease

Possesse great Land-lords; who, for rebell Groundes,

Do Racke their Rents, and idely live on these;

Or spoyle their Tenants Cropp with carelesse Houndes.

But this rare Spirit, (that hath nor Flesh, nor Bone, But Man even in the Abstract) hunts for Wealth

With Witt, that runnes where Profit should be sowne By wholesome Paines; so, reaps both Wealth, \& Health.

Whether the Cost, or Time, which he hath spent

Be most, it's hard to say : for, twenty yeares

His Pounds, by thousands, he his Grounds hath lent,

Which payes now use, on use, as it appeares.

The Place wherein is fall'n His happy Lott

Hight Golden-Valley; and so justly held :

His Royall TRENCH, is as his melting Pott,

Whence issues Liquid-gold the Vale to gild!

O that I had a World of glorious wordes,

In golden Verse (with gold) to paint his praise,

I would blinde Envies Eyes, and make Land-lords

By this Sunnes rising; see their Sonnes to raise.

But $\hat{o} !$ this is not all thou dost behight

Deere Vaughan, thy Deere-Country for her good;

For, thou resolv'st to raise that $(a)$ benefit

Out of thy private care; and Liv'lyhood.

(a) The

Countries

Thy good. 


\section{A PANEGYRICKE.}

Thy many trades (too many to rehearse

That shall on thy Foundation stedfast stand)

Shall with their Praiers, still the Heavens pierce;

And blesse their Founders rare Head, Heart, and Hand!

That publike Table which thou will erect

(Where forty every Meale shall freely feed)

Will be the Cause of this so good Effect

To plant both Trades and Trafficke there with speed.

There shall thy Jovialist Mechanicalls

Attend this Table all in Scarlet Cappes;

(As if they were King Arthures Seneschals)

And, for their paines shall fill their Chapps and Lapps.

For, never since King Arthurs glorious dayes (Whose radiant Knights did Ring his Table round)

Did ever any such a Table raise

As this, where Viands shall to all abound!

Nay this, shall that franke Table farre exceed

If we respect the good still done by each:

For, that fedde none but such as had no need;

But this (like God) shall feed both poore and rich!

This Table then (that still shall beare thy Name In Hyrogliphicks of the daintiest Cates) As oft as it is spread shall spread thy Fame Beyond the greatest conquering Potentates! 


\section{A PANEGYRICKE.}

They spill with spite, what thou in pitty spend'st;

They onely great, thou good, how ever small;

Subversion they, Erection thou intend'st;

They foes to most, but Thou a friend to all.

Thy vertuous care to have thy God ador'd

(Among thy Paines and Pleasures) all will blesse:

Thy Pension for a (a) Preacher of his Word, Shewes thou seek'st Heaven, and earthly happinesse.

(a) Preacher \& Curate for daily service.

A Chappell and a Curate for the same

(The one maintain'd, the other built by Thee For Gods Diurnall praise) shall make thy Name In Rubricke of the Saints enrold to be.

Thine Almes-house for thy (b) haplesse Mechanicks Shall blaze thy charity to After-ages; And longer last in Brests of men, then Bricks; Increasing still thy heavenly Masters Wages.

(b) Any way mischanc't in their Bodies, so that they cannot work.

If holy David had great thanks from Heav'n But for the Thought to make the (c) Arke an House; Then thanks of all, to Thee, should still be giv'n (c) 2. Sam. 7. Whose purpose is to all commodious.

O happy Captaine! that hast past the Pikes Of sharpest Stormes, still wounding Soldiers states, To end thy Dayes in that which all men likes, Joy, Mirth, and Fellowship which ends debates. 


\section{A PANEGYRICKE.}

The Drummes and Trumpets (Mars his melodie) That wonted were to call thy foes to fight, Shall now but call a friendly Company. (For honest ends) to feasting and delight.

Glory of Wales, and luster of thy name, That giv'st to both sans Parralel'd renowne, Upon the Poles inscribed be thy Fame, That it to Worlds unknowne may still be knowne.

(a) What is before expressed.

That they may say a Nooke but of an Isle That North-ward lies, doth yeeld a rarer Man, Then larger Lands by many a Thousand Mile, Who can do (a) Thus, and will do what $\mathrm{He}$ can.

But many Monarches, many Worldes have wonne, Yet, with their Winnings have not wonne that praise As this great-little Lord of hearts hath done, For good-deedes done to These, and After-dayes.

Now Envy swell, and breake thy bitter'st Gall With ceaselesse fretting at these sweete Effects, Th' eternall good which he intends to all His Fame (well fenc'd) above a Foile erects.

Liv'd He among the Pagans, they would make

(b) Like Mars, Jupiter and Saturne.
His glorious (b) Mansion some auspicious Starre; And make their Altars fume still for his sake As to a God, to whome still bound they are. 


\section{A PANEGYRICKE.}

For, Bacchus but for planting, first, those (a) Plants

Whereby mens Wealth, and Witt are oft ore'throwne

Which wanton Nature rather craves, then wants,

They, as a God, with Gods do still enthrone.

But let us Christians, though not yeeld Him this,

Yet give him Love and Honor due t' a Man,

That makes men live (like Gods) in Wealth, and Blisse,

And heave his Fame to Heaven if we can.

Vaine Hanno taught his lesse vaine Birds to say Hee was a God: and then he turn'd them loose That they abroad might chaunt it still; but they (So gon) with silence prov'd their God, a Goose.

Then, though no God he were, yet might $\mathrm{He}$ be A right (b) God-keeper in the Capitoll:

They Geese (at most) and so (at least) was $\mathrm{He}$;

Or, if ought lesse, his God-head was a Gull.

But what I say, none taught me but thy Worth;

Nor shall it (like those Birds) thy Fame betray:

(b) Geese (by reason of their vigilancy) kept the PaganGods in the Romaine Capitoll.

But these my Lines shall then best sett thee forth

When thou art worse then Wormes, and lesse then Clay.

As well thy Crest, as Coat (ô wondrous thing !)

A Serpent is, about an Infants Necke:

Who was thine Ancestor, as Bards do sing,

So borne (alive) the Fates to counterchecke. 


\section{A PANEGYRICKE.}

From him thou cam'st; as one, in him preserv'd ; (By way of Miracle) for this good end, As, by thy skill, to have so well deserv'd Of all the Kingdome, which it much will mend.

This praise (perhaps) which thy deserts exact, By Envy will be thought poeticke skill, Playing the Vice, but in a glozing Act, And so wrong Witte to sooth an erring will.

But yet if Arte should leave true Arte unprais'd, (The only Meed the Time all Arte affords) What Spirit by Art, would then at all be raiz'd (From this Worlds hel) if Art should want good words?

Then, be the mouth of Envy wide as Hell Still open in thy spight, yet say I still Thy praise exceeds, because thou dost excell

(a) Good In these thy works, that worke Good out of (a) Ill.
Grasse out of ill ground.

If I be lavish of good-words; thou art As lavish of the good which thou canst do: Then, must thy praise be greate-good, like thine Arte, That goods thy praisers, and dispraisers too.

In short (sith on thy praise I long have stood Whereon my verses Feete do freely fall) As thou dost ,worke by Flouds, so th' art a Floud Of working, running to the Good of all. 


\title{
A PANEGYRICKE.
}

For as the Sunne doth shine on good and bad; So doost thou (Sunne of Use-full Science) still :

Then, Floud, and Sunne, thou art the ground to glad, And make it fruitfull to the good and ill.

But sith th' obscurest Sparke of thy bright (a) Tribe Speakes thus of Thee, (thou small-great man of worth) It may be thought I praise to thee ascribe As part mine owne; so falsely, set thee forth:

(a) Descended from his Ancestors.

But those, so thinking, when thy Worth they proove, With mee, will thee both honor, praise and love.

\section{Your poore kinsman,}

and honorer of true vertue in whome so-ever.

\author{
JohN Davies \\ of Hereford.
}




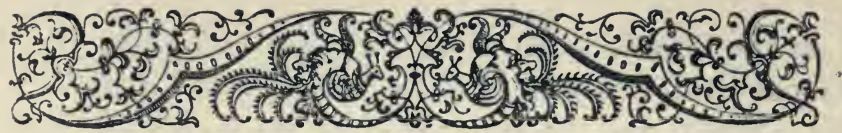

\section{In praise of this no lesse pleasant}

then most profitable worke.

Oe heere a worke; a worke? nay, more then so, A worke of workes : for all it doth containe Makes wealth by Water, over Land to floe, Where-to workes runne, that reach to honest gaine.

Then, hast thou Land? and Water there-with-all ? A little Land and Water so may stand, That Land shall rise by that small Waters fall To high esteeme, and raise thee with that Land.

This is no Dreame; or if a Dreame it bee, It is a Golden one; and shewes by It That golden Worlds of wealth shall compasse thee If, in this dreame, thou act this worke of Witte. Then shalt thou (waking) see (for thine availe) Thy Grasse all Golde as in the Golden-Vale. John Strangwage. 


\section{In Libri Auctorem.}

$7 \mathrm{He} B e e$ is little, yet esteemed much,

1 (With no lesse cause) for Workes as sweete, as rare:

Who, but with Dewes, doe make their owners rich;

And, but for others, worke with ceaslesse care.

Then here's a hony-Bee, that, but with Dewes,

(Exchequer'd in some Trench, as in a Hive)

Sowre grounds with Milke and Hony over-flowes,

Whereon both Hee and Others sweetly live.

Which, not so much for his owne good, he gets;

(Though (like a $B e e$ ) at need, hee feedes thereon)

But to fill others too, with honyed Sweets;

So, with a $B e e$, holds just comparison.

In this they differ; Bees for this doe dye,

But $\mathrm{Hee}$, for this shall live immortally.

Rob: Corbet. 


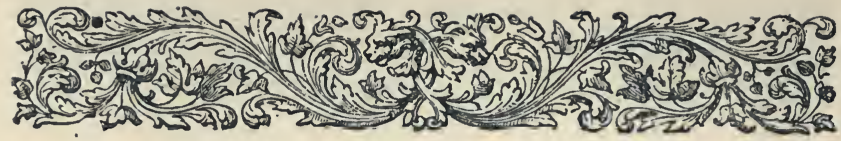

\section{In praise of this most profitable worke.}

YO Plant can prosper if it water wants, 1 Nor Herbage flourish in a thirsty soile; But give that Drinke; with water ply your Plants, And both will yeeld you profit for your toyle.

Some Grounds yeeld Cellers, wherein Nature putts Her choisest liquers to refresh the Mould; There, Founts, and Channels, for their Streames, she cuts, To cheere the Grounds where they their course do hold.

But Natures providence but little bootes, Where water runnes at waste along the Land; None giving drinke unto the thirsty Rootes, Out of those Cellers, being hard at hand.

Then to the Common and the Private weale, How deere is hee that doth this arte reveale?

Henry Fletcher. 


\section{To the worthy Author and his worke.}

VAUGHAN, thou hast a Soule surmounting Soules, In high Conceit, and Action; whose bright fire Mounts to the Spheare, that Gaine to Glory rowles, Which Men still seeke, and Gods them-selves desire.

Who, for thy countries profit, doest not spare Thy Paines, thy Meanes, thy Body, and thy Minde; Whose will is bent to make all well to fare By honest labour, in a diverse kinde.

A Project heere thou hast (in pleasant phrase) Objected to the worlds Desiring-eye, That while some practise, some it doth amaze, To see men mar'd, soone made againe thereby. Then sith (like God) thou canst make Men of Clods, We needs must ranke thee with the Semy-gods.

\section{Richard Harries.}




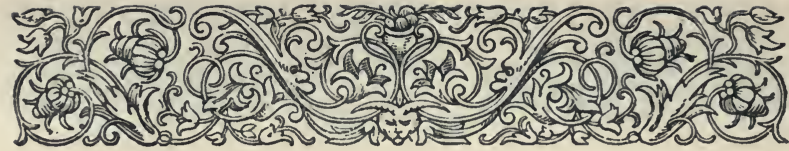

\section{In praise of these most praise-worthy \\ Water-workes.}

BY Fire-workes many have exploited things

Past all beliefe, and made the World admire;

Which Element, beeing on her flaming Wings,

So Active is, that all it strikes is Fire.

That comes to nought, that so is over-come:

But, these rich Water-workes worke leisurely

Most quick increase, in Earths most barren Wombe,

Which beares what One doth ten times sextuply.

Then who beleeves by Fire to finde that Stone

Projecting Gold, much erre in that their Creede;

Sith it is Earth, that's kindly over-flowne,

That is the Stone (indeed) that does the Deed:

Then would'st thou make pure Gold? ore-flow thy land; So, shall thy Soile be turn'd to golden Sand.

Silvanus Davies. 


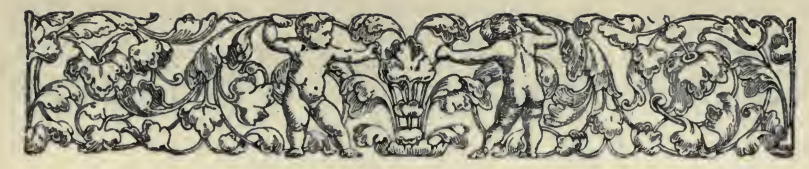

\section{In praise of this as pleasant as profitable worke.}

WOuld'st have great pleasure? then take paines to read This little Tract: which little paines will doe: Look'st thou for profit? then, thou heere maist speed; Where pleasure great brings forth great profit too.

Upon a Subject rude, as is the Earth, Never was Pleasure so predominant:

Nor ne're so blithe was profit at her birth As here, sith here, she is so puissant.

All famous Writers still directly shott The Shafts of their Indevours at these two; For hitting these, they gaine and glory gott; The gaine of Love, and Learnings glory too.

Then love and laud him, who hath close compact Pleasure and profit for thee in this Tract.

Tho: Rant. 


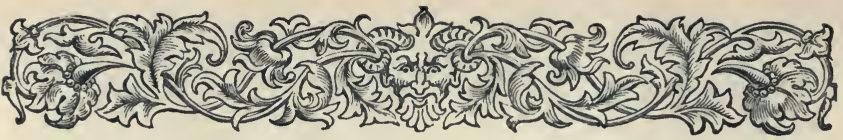

\section{In the praise of the Author and} his effectuall workes.

Eere Rowland, let thine Oliver have leave, Among thy Lauders, his short Breath to spend, To helpe them so, to Heav'n thy fame to heave; Whose Workes are Meanes t'an Earthly-heav'nly End:

Then, Rowland, take me with Thee Here, and There; That Rowland still may have his Oliver.

Oliver Maynson.

\section{In praise of the Worke and Author.}

MY little ROWLAND, you may looke that I (All things considered) $M U C H$ should say of you : Then, this your WORKE (to say that $M U C H$ in few)

Shall worke the Workers endlesse Praise: and why? "A worldly Witt, with Heav'nly Helpes indow'd, ", Getts Ground, and Glory of the Multitude.

John Hoskins. 


\section{Once more for a Farewell.}

In deserved praise of this never-toomuch praysed Worke.

Good Wine doth need no Bush: (Lord! who can tell How oft this old-said-Saw hath prais'd new Bookes?) But yet good Water (drawne from Founts and Brookes) By Sluce (the Signe) makes dry Groundes drinke it well.

Men may have store of Water, and dry Land;

Yet, if they draw it not through Trenches fitt,

(By Sluce, that shewes how (well) to utter it)

It idely runnes, while scarse the Owners stand.

Good Water, then by Sluce, through Trench must passe For good returne; that else runnes to no end; Which Signe doth draw it in, it selfe to spend On dryest Grounds, that (drunken) cast up Grasse;

Which giddy Simily, in sober Sence,

Shewes the Effect of this Workes excellence.

John Davies. 


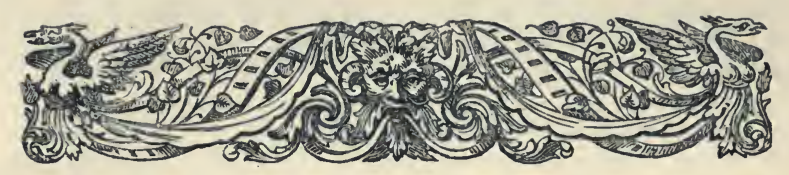

\section{The Author.}

I Would not feare with Cinick Doggs to fight 1 Came they in Front: But, this will ill be borne; Perhaps some Curres behind my Backe will bite: But that's their shame, my glory it to scorne.

\section{Rowland Vaughan.}

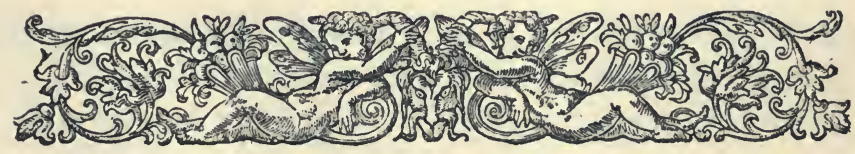




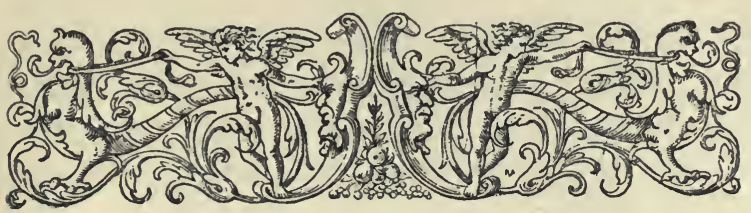

TO

THE RIGHT HO-

\section{NORABLE WIL-}

IAM EARLE OF PEMBROOKE Lord Herbert Of Cardiffe, Marmionand S.2uintin; Lord Parre of Rosse, and Kendall; Lord Warden of the Stanneries:

Captaine of his Majesties Garrisontowne of Portesmouth; and Knight of the most Noble Orderof the Garter;

My most honoured and respected Lord.

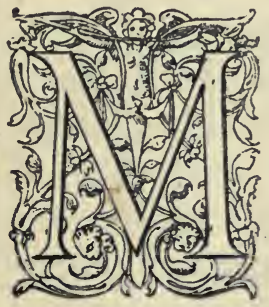

OST HONOURABLE, and my Noblest Lord: I have out of my lives experience, prepared a Watry workemanshipp, which I thinke the Gods forbad the excellent creatures in former times to handle ; but I have performed That, that hath begott a world

C 25 of 


\section{WA TER-WOR K ES.}

of worke in $\mathrm{Me}$ (which some men say will either impayre my witt, or hazard my estate (they said so in the execution of my water-workes (but they over-said them-selves, and the most part have given mee satisfaction by maine submission or reconciliation) I doubt not but the rest, in my mechanical undertakings, will doe the like, because some have subscribed, and many offer conditionall pertakings.

What blessing soever Invention doth raise, your Lordshipp knowes is subject to a hotch-potch of speach ; and untill it bee performed, Envy, Mallice, and all spitefull detraction follows; so is it with

(a) Custome is a great Lord of Command. me. But (my good Lord) seeing that $(a)$ Lordly Custome wils that great Lordes should patronize Invention; I doe most humbly beseech your Lordshipp (on my behalfe) so to doe; you beeing (next unto my deare Soveraigne and His) heire apparant to my heart; having intaild my dutifull services to the heirs male of your body; and for want of such issue, to the heirs male of my Lord of Mongomery, for ever, without revocation; these affections, proceed not (my honourable Lord) from any sinister respect; 26

these 


\section{W A TER-W O R KES.}

these following considerations be the cause: The remembrance of that worthy Prince your Father, and more worthy (if might be) your Grand-father, and great Grandsiers, from the battels of (a) Cressy, Poytiers, Egincourt, and Banbury, with many others before, and since. Where the many services of mine to yours hath bene such as Tradition will tell your Lordshipp, and I tell you with all, the aboundant favours we found, makes mee thinke my selfe bound to your Lordship in recognisance of duty, and you tyed (by honourable and parrall covenants from them, to protect me and all my indevors, laboring for the good of the commonwealth, and your glory. Now, if I make it not appeare a most flourishing common-wealth; and such as never poore Subject in the Kingdome did raise, put me by with your hand, as unworthy of any favorable respect.

Your Lordshipp shall finde no Monopole required; but, this I require at your handes: In matters of common-wealth, Expedition is alwayes of the 2uorum; It is one of the chiefest friends (my Lord) the Suter (except he be a wrangler) hath

(a) In these several battels, the Vaughans mine Ancestors followed yours. 


\section{WATER-WORKES.}

in all the Kings courts : therefore I can require no lesse then that your Lordship command I may have convenient accesse, without restraynt to performe my common-wealthes desires, with these limitations and due observance, that I disturbe not your Lordships quiet, nor conferences, with honourable persons, \& others of accompt: watching, \& taking the advantage of Time, and Place; a word at one time, and two at another. Thinke not (most Noble Lord) that I am eyther insolently saucy, or too bold. Your Lordshipp shall here-after understand the quality and condition of my undertakings will admit little delay; I speake partly out of the complaint of an old servant of your Grandfather Pembrookes, my Uncle Thomas Vaughan: who was to take his tryall for his life at Kings-bench-Barre at tenne of the clocke in the morning, having forgotten my Lords remembrance to some good friend, prayed passe of the Groome of his chamber being French: who with hard wordes stopped his passage; but he putting one of his Armes betwixt the French-mans twist, the other about his necke, threw him at my Lordes 


\section{WATER-W ORKES.}

feete, and told his Lordshipp the cause was, he came for his life: My Lord hearing that, allowed this his coming with a vengeance, in respect of his necessity to prevent a mischief, and with patience priviledg'd the offence, beating the Groome for his ill respect : So good my Lord, make me free of your presence ; and command your principall Attendants (as Secretaries, but especially the Gentlemen of your Chamber, and Groomes) to take speciall notice, $\mathrm{My}$ comming is to doe you all honour. If I should attend Houres, Times and Seasons, I should bee in that case as if I weare to deale with your Lordship by Petition, $\&$ to purchase your speach with a price, so the memory of three hundred yeares dependancy should be trodden under foot as of no value.

As Lawyers not fedde every Tearme, breeds neglect of their Clients, with discontinuances and cessations; so, your Lordshipp may handle the matter, and post me over by discontinuance, that you will forgett I have not done my duty this two yeares and more. But your greatest and dearest Servants 


\section{WATER-WORKES.}

(a) Builth.

can witnesse my appearance: Though happily not furnished with such glittering Garments as might light my way to you : for, Scarlet of (a) Bilth (Welch frizes other name) hath now little grace amongst great ones: But the Hood makes not the Fryar, nor a brave Coate a brave man.

Now be it knowne to your Lordship, and to all men (with the helpe of my Lord God, the Kings most excellent Majesty, and you my deare Lorde:) I purpose to raise a golden world (for commonwealth) in the Golden-Vale in Herefordshire (being the pride of al that County) bordering on Wales, joyning to Ewyas Lacy (from whence your Lordshipp is descended) being the richest: yet (for want

(b) The of imployment) the plentifullest place (b) richestCountry breeds the idlest (therefore the poorest) people. of poore in the Kingdome, yeelding two or three-hundred-folde : the number so increasing (Idlenesse having gotten the upper hand ;) if Trades bee not raised; beggery will carry such reputation in my quarter of the country, as if it had the whole to halves. Therefore (my honorable Lord) put not onely your hands, but all your will and all your strength hereto, 


\section{W A TER-WORKES.}

praying my Lord of Moungomery to assist your Lordship (if there bee cause). Let it be Vaughans supplication of Beggers unto his Royall Majestie, that they may have meanes to work, and so to live.

There bee within a mile and a halfe from my house every way, five hundred poore habitations; whose greatest meanes consist in spinning Flaxe, Hempe, and Hurdes. They dispose the seasons of the yeare in this manner: I will begin with May, June, and July, (three of the merriest months for beggars) which yeeld the best increase for their purpose, to raise multitudes: Whey, Curdes, Butter milke, and such belly-provision, abounding in the neighbourhood, serves their turne. As Wountes or Moles, hunt after wormes, the ground being delve-able: so, these Idelers live intollerablie by other meanes, and neglect their painfull labours by oppressing the neighbourhood. August, September and October, with that permission which the Lord hath allowed the poorer sort to gather the Eares of corne, they do much harme. I have seene three hundred Leazers or Gleaners in one Gentlemans corne-field at once; his servants gather3I

How the poore of the country dispose of the seasons of the yeare. 


\section{WATER-W ORKES.}

ing \& stouking the bound-sheaves, the sheaves lying on the ground like dead carcases in an over-throwne battell, they following the spoyle not like souldiers (which scorne to rifle) but like theeves desirous to steale; so this army holdes pillaging Wheate, Rye, Barley, Pease and Oates: Oates, a graine which never grew in Canaan, nor \$gypt, and altogether out of the allowance of Leazing.

Under coulour of the last graine, Oates,

The Beggers good husbandry of my countrey. it being the latest harvest, they doe, without mercy in hotte bloud steale, robbe Orchards, Gardens, Hop-yards and Crabtrees: so what with leazing and stealing, they doe poorely maintaine them-selves November, December, and almost all January, with some healps from the neighbourhood.

Thus your Lordship sees (before God and the world) the principall meanes of their maintenance. The last three moneths, February, March, and Aprill, little labour serves their turne: they hope by the heate of the Sunne, (seasoning them-selves like Snakesunder headges) to recover the month of May with much poverty, long-fasting, and little-praying: and so make an end 
of their yeares travell in the Easter holydayes.

There is not one amongst ten that hath five shillings to buy a Bale of Flaxe, but forc'd to borrow money to put up their trade, and runne to Hereford (loosing a dayesworke) to fetche the same: Thisdone, they bee driven to buy halfe a bushell of corne three or foure miles off, and in their returne attend the grinding of it ; which if a better Customer come, they are sure to be served last. Withall, they spend one day with the Weaver, and after it is wove, before they can sell, they make many journeyes to markets, and honest mens houses: And thus many dayes are mispent in most miserable maner.

Now (my Honourable Lord) to helpe all these miseries; I have, out of a yeares consideration, put a foote a Remedy which cannot well bee done, unlesse your Lordship doe promise to countenance my discovery; if you do, Ile make your glory shine as farre above all other Subjects, as my Plot is hatefull to many envious persons.

My Mill is my first Worke, governed by a little Bastard-Brooke, fedde with

The meanes to amend the Countries misery.
The first worke is the Mill. 


\section{W ATER-WORKES.}

eight living Springs, built with no desire to intertaine Customers, but onely to grinde mine owne corne.

In my first Foundation, the Countrey said I should never bee able to performe the same. They said with-all, I could not command the water; and that I should want custome to countervaile the charge. I have built my Mill, and acquainted the water with his course. Unto this Mill, I build all Offices and necessary roomes serving my Mechanicals.

The use of the dyningroome.

Officers.

Trades.

The dining roome to entertaine Knights and Gentlemen : Buttry, Pantry, Kitchin, Larders, Pastry, Surveying-roome, Backhouse, Brew-house, Sellors, Killning for Malt, Slaughter-house, Sellors belonging to the Slaughter-house, Uting-roomes, Garners, Malting-roomes. Officers; the Clarke, Miller, Loder, Malt-maker: Butcher, Chandler, Cookes, Bakers, Brewers, Tanner, Shoo-maker, Cobler, Glover, Currier, Sithe and Sickle-maker, Nayler, Smith, Joyner, Cooper, Carpenter, Gardiner, Mercer, Cutler, Barber, Stocking-knitters, Hosier, Lanthorne-maker, Fletcher, Bowyer, (holdbreath). The Taylor, Sempster, Launderers, 


\section{W ATER-W ORKES.}

derers, Wheeleer, Card-maker for Spinners, Hatter, Point-maker, Sheapheards, Hindes, Dairy-people, Swinheards ; two Vittelers, and a noyse of Musitions with the GreeneDragon and Talbot.

If I mistake in marshalling my Mechanicals, your Lordshipp must understand I am no Herold: they be a disordered Company; the offence not great to place one knave before an other. All which be appointed Attendants to maintaine and furnish $(a)$ twenty broad Loomes for the finest cloth ; tenne narrow Loomes for courser Wooll, Flax, Hemp, and Hurds. Tenne

(a) Twenty broadloomes imploide for fine cloth. Fustian Loomes, with such Silk-loomes as necessity shall require : A Walker, Dier, Cottoner, Sher-men, Spinners, Carders, Sorters of wooll, pickers, and Will-winders; which number will rise to some (b) two thousand and upward. For all which (except Spinners and Carders) I find convenient house-roome. They shall never loose an houres time to provide for such meanes as the backe or belly requires: bread, beefe, mutton, butter and cheese of mine owne provision, shall attend their appointed houres, without their trouble or losse of labor to any

(b) Two thousand imploide in the under-businesse of the Commonwealth. 


\section{W ATER-W ORKES.}

Market or other place, at the best rates of the Kingdome, unlesse it bee in the Mountaines, where Oren Glindour was shutt up: A place unfit for Trades. There, a Crafts-man may have twenty Eggs a penny, a good round Bullocke for two Markes, and other necessaries rateably.

The Golden

Valley is the Paradise of al the parts beyond Severn.

But I speake of the Golden-Vale, the Lombardy of Herefordshire, the Garden of the Old Gallants and Paradice of the backside of the Principallitie. I protest, had I foure little Livings joyning to some I have, I would not change my poore estate to bee great Duke of Muscovia, where the flesh falles from the face in a frosty morning, like Lime from a Seeling soaked with Raine. But to prosecute mine argument, and that your Lordship shall not thinke I forget my selfe, I must let you know they shall neither Roste, Bake, nor Boyle: mine owne Range, Ovens, and Furnesse, shall ever doe them that service with-out their trouble or charge, with little losse unto mee. All Trades under my obeysance, shall bee at their election, whether they will buy their flesh Rawe, Roasted, Boyled, 


\section{WATER-WORKES.}

or cold. No Trades-man shall rate his owne commodity, but the Clarke, Recorder of the company, (being of the quorum) shall say to the Tanner: you bought so many hundred Hides of my Maister, you may affoord a Dicker of Leather at such a price: and Shoo-maker, you, your shooes at such a price. You Glover, bought so many thousand Pelts; you may afforde your Gloves at such a rate. And so every Artificer shall bee limitted to Marchandize each to other, at rates reasonable agreeing with their good gaine. But for all out and In-commers that will traffick with my Mechanicals, I leave them subject to their fortune. I will have but one of each trade : as a Tailor, with as many servants as his Tailorship thinkes good: and the rest, as each trade requires. I hope (my Lord) I have told you comfortable newes: yet I will increase your comfort, with comfort upon comfort: and so comfortable, that all our company will turne their Songs, and Carrols, into singing of Psalmes and Himmes to the honour and praise of the living Lord, the Kings most excellent Majesty, and your Lordship. But before

The commerce of the Company.

But one of each Trade. 
A famous preacher shall be maintained.

\section{WATER-WORKES.}

we shall bee able to sing in tune, you must be Maister of the Musick, and Organist with all.

Now I have made knowne unto your Lordship my morrall and Mechanicall mysteries, you see what preparation I have made for the body: If care be not had for the salvation of the soule, all my buildings and foundations bee shuttle and sandy. I am by the vertuous and honest Gentlemen, and others in my neighbourhood, importuned to raise a famous Preacher amongst them. Their importunity shall not need, I will desire onely their assistance with but a little more helpe then my owne; your Lordships favour ever assisting us. The case stands thus. There came unto mee, a dozen yeares since, a yong Minister, having a good witte, a good memory, and a pritty dribble of learning: who made himselfe fitte to teach children. Hee was intertained like a Levite; and had the liberty of a Levite; but with-in short time hee became a counterfeit Puritane. Under coulour whereof he ingros'd halfe the good opinions of the Parish, to retaile them to his profit and advantage, 


\section{WATER-WORKES.}

and though himselfe were presisely given, yet hee did little harme : I know not that hee hath reconcil'd any to that quick-silver-brain'd pure faction (as good hap is). I had ever a good hope, that hee would subscribe, and obey the Cannons and Institutions of our Church, as hee did.

A Benefice being voyde neere unto mee (in her late Majesties gift) an honorable kinsman of mine, gave mee the presentation for this counterfeit. Hee had Institution and Induction according to the common course: but (my honorable Lord), as every licquor serves not to coullor all coulors: so, every soyle fitts not every person. Hee had no sooner received the benefit of this Benifice, but the principall of his parishoners told mee I had planted a Machivel amongst them; a cunning Pollitician, and an horrible usurer, making complaint to the Bishop thereof. But (my good Lord) because he had bin my servant, I praide the Bishop with patience to heare his defence, and for that time prevented the likely-hood of his disgrace. Where-upon I wrought with him to depart with that thing, and had

Three speciall vertues to withstand the Flesh, the World, and the Devill. 
agreed for his remoove, with a purpose (as the Bishop doth know) to plant a famous Preacher there, and told him all my intendiments: and to that end I most humbly praide the Bishop that it would please his Lordship, to give liberty to one of his Chaplins, a learned and vertuous man (Maister Best) to bee the man. That one living of his, not able to maintaine a preaching Minister, there was one other joyning thereunto, which wee purpose to unite: Having gotten the consent of the Lord Bishop, with promise of his best indevour. But (my honorable Lord) here comes in the hindrer of the salvation of soules, this counterfeit Puritane, this Machivillian, this politician, \& Usurer, by the gift of a friendlye Patron, hath as yet gone beyond the uniting of these Churches; and disapointed us of

Policy, in wordly businesses, prevails more then Piety.

our Preaching-Minister, (as I learnt) by plaine symonie; and some treachery (withall) to his old Maister. There were not two Sermons in the Golden-Vale this 500. yeares, unlesse some Circumselion came by chance, untill my Lord his Grace, that now is, of Canterburie his coming to that See. Now, whether we deserve 


\section{W A TER-WORKES.}

to have a Preaching Minister or no, we appeale to the World.

There was an old Monke uppon the dissolution of the Abbey of Doier, that was cast from thence, came unto the place where this Minister serves: Hee did expound without licence, devide and sever the corps of the word, from the Spirit; so spoyling the Scripture with idle intentions, that at his end he left neither Protestant, Puritane nor Papist; but a few of the simpler sort, more inclined to Masse then to sound $\mathrm{Re}-$ ligion. And of late, the late Canons do straightly appoint foure Sermons, yearly. In this manner (My Lord) this Machivilian, Polititian, and Userer having gotten two Benifices, thinks it sufficient with his eight-quarter Sermons in his two Churches, to cleare the infection which the old Monke bred: Hee not cunning ynough to dresse and cure the crazed of his flocke, hath onely judgement with his Hooke to catch and hold a sheepe ; which by over-hard handling hee doth so bruize, that now they can by no meanes indure that all-catchingfast-holding Instrument.

D 


\section{WATER-WORKES.}

(a) A most unholy-holy kind of Usury.

And of late hath lent a young Preacher (being his prime practise) ten pound in money to make eight (a) quarter-sermons yearly: which Preacher venters his life sixteene-times over the great River of Wye, and as many more upp and downe a huge hill lying in his way; the danger of the least of which is able so to distract a good Schollers memory, as to forgette a Sermon well pend, and no worse cond. I have wondred many times of the young Preacher, who did but learne to preach the other day, how hee was furnished with one in the fore-noone, and another in the after: Heerein shall I use your Lordshipps meanes, that wee may have this Userer removed. It must bee done; and $I$ thinke this to be the best means: Your Lordshipp may commend him to some strange Ambassadour out of $A$ sia or Africke; not in Europe, hee will learne the Language instantly: Hee is fit for any strange Religion. Hee will serve for an Intelligencer to execute any cunning Stratagem belonging to matters of State. When your Lordshipp hath understood the trunesse of all my intention (which happily you will runne over with 
all expedition), like an old Priest (a) reading an Homily to taske, (which I wish not.) Then will you undo all the hopes I have, in with-standing the pride of many ill speakers.

If you doe not particularly examine, that you may bee able to defend, and report that wee build no Monasteries, nor succor Seminaries, nor much respect unpreaching Ministers.

Wee build our Church which is downe: A Chappell (b) for Prayer for all my $M e-$ chanicals: A famous Preacher to rectifie their hearts and shew them the way to Heaven: These, with an Almes-house (my Lord) to provide for the over-aged persons, lame, blinde and all such as necessity doth cause to for-beare their own gettings. Your Lordship doth see I am no Papist, nor Puritane, but a true Protestant according to the Kings Injunctions. And where the Puritans babble against one Minister to have two Livings, lett the Superintendant of them, with some other of their purified number, come to the Hundred I dwell in, (which, is Weabtre) I will shew them foure and twenty parishes; not any one of all able to

(b) Chappell built, and a Curate maintained. 


\section{WATER-WORKES.}

Twenty foure Parishes in Webtre hundred, and not one able to maintaine a Preaching Minister. maintain a Preaching Minister. If these be they whome they call Puritans that speake against a Preacher to have two or three Livings together in my Hundred; I wish I were a poore Burges of the honourable House of Parliament, then would I indeavor to diet them so for Livings, that I would make them fast Extempore, as well as pray, and preach as the Spirit prompts.

The most men now doe say, if I hadde money ynough, I might performe my undertakings. So (my Lord) if a man had money ynough (with the LORDS permission) Hee might build a Towre of Babell. I cannot see how mony can be wanting, I have so many honourable friendes; Lords Spirituall and Temporall, Bishoppe Babington, Bishopp Benet, and Bishoppe Parrie, grave and venerable Prelates of the Kingdome. Lords Temporall: Your Lordshippe, my Lord of Montgomery, with many other great Lordes (my Kinsmen) I meane not to trouble: Only my deare Lord the Lord cheefe Justice, and one Judge more, who is a Lord in Westminster Hall, I hope to see him a Lord to the last : And doe tell 


\section{W ATER-WORKES.}

your Lordshippe (betwixt you and mee bee it spoken) Hee is one of the best Lawyers in the Land; else very good ones are deceived; and though hee bee so, let him use what dilatory Plea hee list to putte me off, I meane to putt his Purse to the push of the pike: Hee said hee would doe nothing therein : but, hee sware not; or if hee had, I know hee makes a difference betwixt Mee, and a Rash oth. But to our purpose; Your Lordshipp is now become Generall of that Army; and I your Lieutenant; If any muteny against our Common-wealth, or speake (out of a hott brain'd humor) that that they understand not: My Lord, silence them with your wisedome, or defie them with your power, which can never bee better imploid in worldly respects, then for the protection of a Commongood. Though all the world should say I should want money in my first beginnings, yet I thanke God they cannot say I want honorable friends, such as the Lord Bishops, your Lordships with others; which may lend me money (if please you and them) I wil not for a million anger any of you, to make a motion to 


\section{WATER-WORKES.}

Beginning is halfe the whole.

borrow money : if lendings come in out of your honourable dispositions, I would I might never put upp my Trades, if I refuse any for a yeare, two or three. Its a better course (tenne to one) then to take money to usury; knowing what I know: and I know as much (perhaps) that way as any poore Gentleman in Wales (without vaine glory bee it spoken). First (my Lord) hee that will take money uppon usury, must deale with the Scrivener in Dialogue manner; thus for example: Sir, have you any money? What is your name (saith the Scrivener). Sir Brute Bankcrout Knight, late of Hadland in the County of Cumberland. Who bee your sureties? Sir Alexander Allspent, and Sir Lancelot Little-left. I know them well; worshipfull Gentlemen : But I tell you (Sir Brute) you must finde Cittizens: The Scrivener (withall) rounds the Knight in the eare, saying, The World is dangerous and full of iniquity, but if your worship can procure such and such Townes-men, you shall commaund my paines from sixe to sixe months. Now it may bee Sir Brute, with Sir Alexander, and Sir Lancelot, may spend 46

sixe 


\section{WATER-WORKES.}

sixe times sixe dayes (unlesse they meet with a deare friend to furnish them after twenty in the hundred) before their turne bee served. Once (my Lord) I thought to borrowe a hundred pound at a Pinch, but the Gentlman that ow'd the money would not traffick with me because I dwelt beyond Severn. A foule indignity to your Lordshipps Havings, having such royal Livings in Monmouth and Glamorganshire. I beseech your Lordship order may be taken that we may be as free of the Userers Courts of Requests as other Shires be; we are out of the principallity, and the Kings Subjects : then to bee barred from those Benefits \& Immunities which the Law doth alow, were lawlesse and unreasonable. Our Shire is a Shire-royall; and we pay as royally for our usury as if we dealt with (a) Jewes, the cursedst Generation of all Adams children. Another time I dealt for a hundred pound with an Userer Hold-borne-ward; and having neglected my Houre, his Wives Sheettravell with him by night, gave (O course fortune) my dayes labour the Ganvase: $\&$ driven to become suter to her mighti-

(a) Userers are Jewes by their trade. 


\section{WATER-WORKES.}

nes (great Princesse of darknes) so what by meanes of som ells of Lawn, a Sugar loafe and a paire of Silke Stockes (wooden ones being much more meete) I was beholden to neither of them, thankes be to my meanes: But missing my day, with this consideration taken he set Sentinell two Sergeants, on the height of the Hill neare Paules; I shall never forget the fashion of their faces, two Orange-tawny beards in a bloody field (Gules, my Lord:) they walked as if they would have overwalked me; but having gotten my broadside they said stand. I had the word ready, at whose sute? (thinking I had bin in the wars and they Sentinells to give passe) they brought

(a) Counter in the Poultry. me to a (a) Garrison neare the Exchange garded with a number of $V$ arletiers. God knew my heart when I saw all Halberds, and no Muskets, for then I thought the dispatch in mine execution would be the slower; howbeit, I did with as much speed as I could, ransome my selfe: I speake not as if it tended to provoke any of your Lordships to pitty me; but to lesson such young Gentlemen as (at careles liberty) serves under your Lordships coulors that they accept of no office under 48

the 


\section{WATER-WORKES.}

the Userers or Brokers cheek : your Lordship shall have many of the Nobility (out of their honorable zeale to publike profit) commend my Common-wealth, yet if any of them (like Puritans) turn with zeale to lend me money to so good a purpose, the heavens fore-fend that I should quench it; no, it is good to bee zealous in a good matter.

Thus having tyred your Lordships attention I thought to have made an end; but my love to you exceeding the ordinary love of men, drawes me on to trouble you further for your (a) ease.

Once I heard your Fathers name (beeing my Lord and Maister) ill spoken off by a world of people, and two other great Earles, three Knights, and divers Genlemen, ill spoken off by the inhabitants from Tentarne to Courtydee, on both sides Wye threescore miles a head; I beeing a Servant, the Cause. stood so strong with the Country, I could by no meanes devise how to make a quarrel to defend my Lords Honour. I little thought I should have beene in place to have heard so many ill speakers, and so few defenders, against so many honour-

(a) Strange Paradoxe yet true if a mans increase of estate tends to his ease. 
able persons and others of account and durst doe nothing.

I praid to heare their grievances: They said time out of minde as appeared by their records (kept in the Castell of the Hay burnt by one Owen Glindwr) the River of Wye (their free and Mother River) was (in the troublesome times betweene the houses of Yorke and Lancaster) so weared and fortified as if the Salmons therein (on paine of imprisonment) had beene forbidden their usual walkes; and on paine of death (as in case of high treason) not to trade with any of the Earle of Marches men.

The humble request of foure or five shires will be that your Honors (with the rest) will take pitty on a whole country, groning under the burthen of intollerable Weares, which (for private) are the very Dammes and Letts of Publicke profit. Your three houses with one Lords more having more interest in those shires (under his Majestie) then all other Landlords.

The Counties reliefe rests almost in your Lordships hands; the duty you owe my Lord of Shrewsbury, and his deare 


\section{WATER-WORKES.}

respects of your commands that Weare $\mathrm{My}$ Brother and my selfe being Commissioners in a commission of Shewres, not daring to do our duties without my Lord your Fathers privity (hee having one Weare on the River, being Lord President of Wales and our Lord and Master) wee acquainted him with the Commission and upon my salutation (I protest) he commanded us that his Weare should bee puld downe, if it appeared profitable to the Country. That noble Earle of Worcester with his honorable and vertuous sonne the Lord Harbart, how their weares will be dispensed with-all in these daies all the shires will referre unto their honorable dispositions. For Sir Edward Winter; there is nothing I take it but perforce. true honor in him. My acquaintance with him is but small; yet if I bee not much deceived hee respects more the common-good, then his own private; although (indeed) hee was (to say the truth) upon the last Commission a commissioner very bitter against the Weares over-throw. I saw the reasons thereof, and did allowe of his unreasonable prosecution. Hee showed much witte therein, 


\section{WATER-WORKES.}

and did us more harme then all the rest: God forgive him, and make him as firme to the over-throwers of Weares as he is faste to their upholders. Sir John Scudamore hath always beene the comfort of the country: Nurse to the Infancie of many young Gentlemen bred therein, and Cherisher of the rest that were not adverse. Hee hath ever said, if there were any hope that the over-throwe of the Weares would make the River (Wye) Navigable, Portable or Sammonable, hee

A good offer of a good heart. would pull downe his first, to give an instance to others.

I beseech your Lordshipp, beare witnesse, I say nothing of Sir Roger Bodenhams Weare; nor of none of the Weares above Hereford Bridge. But this I say, its a pitifull thing that any of your Lordshipps Weares with the rest, (built like Babell threatning the skies with their eminence) should hinder the Salmonfishing, which gave that sustenance to five or sixe shires, as many thousands, were a thousand times better susteined and comforted then now they are, or can bee.

All that can be said, why the River $5^{2}$ 


\section{WATER-WORKES.}

cannot bee made Port-able, is; Some Fords when they are at the lowest will want water. A poore and needy speech! As if there were not meanes enough to chanell such shallows, in Summer they being at the smallest, and peaceablest time to bee wrought.

Goodmy LORD, down with the Weares, let us have Wine with our Venison, the carriage of it from London by land, makes a cup of Claret looke like a weake leane wench that hath the greene sicknesse. And such as we have from Bristowe, is fitter to be drunke with a Welsh Goate, then an English Buck.

Wee are barde of our Meate, bound from our Drinke, and many other provisions, which almost all other shires have. During your Fathers life time our hopes were a foote, wee had the Vantgard in the warre: But, since his death, put to the Reare, by occasion of your nonage, and such accidents as bee-fell.

But now seeing your sacred Soveraigne puts his hands on your shoulders (without which the greatest Subject cannot put his hand on his heart, for want of one) forget not (my noblest Lord) to fall at his feete

Bristoll better served with Sacks then Gascoine wine. 


\section{WATER-WORKES.}

in favour of your Fathers favorites. If a Commission of Shewres happen amongst us (by Gods visitation) then I hope you will most earnestly beseech his Majestie, that his Supersidias knock not out the braines of the Commission of Salmon-fishing. The fore-said Supersidias hath alwayes beene our utter over-throw. My good Lord, compare all the Rivers in the Kingdome together; and you shall see and heare by all antiquitie, the River of Wye, did exceede all other for Salmon. These Weares your three fore-mentioned Lordships, with the rest doe owe. They doe you and them but the least service; they bring some fewe of your Salmons in season toyourTable: and a hundred thousand bee served unseasonably. In my memory, it hath bred an inbred murmure amongst us, which hath made the most so melancholy, as I thinke the braines of many be not setled in their true situation. They confesse their error, and report their mis-

It is manly to erre, beastly to continue in error. taking: first, to bee from a worthy old Gentlemen, Maister Philip Jones, who out of a blind zeale (like Papists that goe on pilgrimage) yet wanting the true length of the three Lords legges, (but 


\section{W ATER-WORKES.}

held a true course agreeing with all actes of Parliament) did put a foote the Commission of Shewres, not thinking the Earles of the Land to bee the Gods of the Earth. His yeares worne out, and memory decayed, foure-score odde yeares drawing on the day of his death, never trained at the Counsell-table, durst not presse into the presence, and (like a dotard) did never Nerw-yeares-gift the Ladies of the Privie \& Bed-chamber: then what with illiberality of breeding, some misery and untidy handling, suffered to be shuffled into the Commission of Shewres, friends and foes: so, by often meetings and over-long delayes, harazed and wore out all his hopes in dooing any good. The first Commission having made a peaceable end by Supersidias; the death of which Commission bred more lamentation in three Shires, then the death of three Earles (best common-wealths men) would doe in all England. The last Commission might be played on the Stage: The principall persons were Commissioners; all which had Weares on the River: and all had reason enough to over-rule Baby-Commissioners.

The private is more respected then the publike weale, of men private. 


\section{WATER-WORKES.}

As at a quarter Sessions, one great man will under-take the managing of matters belonging to all the Bench. If poore I, should but speake to countenance a cause (for a wench made woman before her time.) Hee lookes on the one side, as if I were put in Commission onely to certifie Recognisances for Ale-houses: or to give a respective voyce if a faction happen to arise: so, these Baby-commissioners for the River of Wye, hold their Hattes in their hands, the one legge lower then the other, ready to doe all their duties at

Alluding to that in maister Fox his Acts and Monuments. once : and the grand Commissioners (like Bishop Bonner) with Riding-Rods, threaten displeasure, or utter destruction, to all that were not of their devotion towards the Weares. This hath beene the Common course and custome of the Commission of Shewres, to out-countenance the cause by the greatest persons: but, the LORD of Heaven ever so wrought, that the Weare-owners were more beholden to the Supersidias then to twelve men : twelve men having given their Verdit, a Judgement against the Weares : \& after all this a Supersidias! ô ! The consideration of it would have made old Ployden (had 56 hee 
hee beene living) forsweare the Law in his latter dayes. Maister Blonden being of counsell with the Country, it so mooved him (being over-come with puffing and blowing) that hee wrought upward and downward, as if hee had taken a vomit or a purgation. I remember in Queene Elizabeths dayes my Lady of Warwick, Mistresse Blanch Parry, and my Lady Scudamore, in little Laye-matters would steale opportunity to serve some friends turnes; but where and in whome the Supersidias rests at Command, this mystery I would my good Lord would learne; because none of these (neere and deere Ladies) durst intermeddle so farre in matters of Common-wealth. Twenty Commissioners attend the service, whereof foure to be of the 2uorum, ever in place : the greatest men of the number, having no desire to proceed : Many dayes meeting disappointed for want of appearance : the Jewry sworne, their appearance, by penalty, appointed twentye miles off: the twenty Commissioners present, some to uphold, and some to over-throw. In this manner, for a long Summers day (which dured sixe months) wee bare E the

A Trinity of Ladies able to worke Miracles. 
An assault towards, against Chepstowbridge by Salmons.

\section{WATER-WORKES.}

the brunt of all opposition. Our last meeting was at Chepstow, and at the mouth of the river Wye, the Jewry (having day given for their verdit, riding over the bridge) upon a sodaine saw the water swolne with a sea of Salmon. The Inquest enquiring of them what news? they answered by signes (sith they were as mute as fishes) they were bard of their native country, where all their ancestors were bred \& borne: \& in their infancy nursd, till they came to Salmons estate. This moane they made by instinct of nature : the Jury praid they would commit no ryot, but indure the day of the Juries verdict with-out their further approach; and order should happily be taken for egresse \& regresse as of old: The Bridge being in a dangerous case meane while; for it seem'd their so neare coming, tended to no other purpose but to strike up the heeles of the Bridge, not laying his glory in the dust, but the water: For feare whereof (as if the Bridge had lost his heart of Oake) it fell downe (heartlesse-lubber) of it selfe within one yeare following, and for the Salmons further comfort, the Jewrie told

them 
them the great Lords were Lords of the stickes and stakes, not of the River; the River was the Kings : no prohibition lay against them, but that they might lawfully enter into their old habitations and places of resort : onely the great Lords will say, they have three yeares possession, or it may be, chalenge prescription; which cannot be ; you being the Kings Tenants, no time going beyond the King. I am not satisfied, how after such a world of Labour and Toyle by the Commissioners and Furors, that the bare Information of a Weare-owner (perhaps) could annihilate all our painfull Indevors for the good of sixe Shieres with a Supersidias.

If I should forget to tell your Lordshipp it hath beene in the memory of many yet living, that the River of $W y e$ did yeeld Salmon so plentifully as Sturgeon in some partes of Germany: \& that a Hereford-shire servant would surfet onfresh Salmon as oft as a North-Hampton-shire-man on fatt Venison: and since my nativity, till yeares of discretion had over-taken mee, I could not Learne this lesson. For my Foster-mother Woodhill, old mother Webb, and mother Spooner (such Mothers,

there

It is most strange, and yet most true. 


\section{WATER-WORKES.}

there are (my good Lord), though you know not their Fathers) telling the $W$ onders of the Weares so pittifully, as if they hadde beene in the captivity at Babilon: How thirty Salmons were taken such a morning at a draught, and thirty three, at another time.

The Supplication of Beggers so moved the heart of that famous King Henry the eight in his later dayes, that hee did nothing else but platforme Foundations for true and sound Religion.

If these Weares had bin in his daies in

Behead them like Traytors. such manner as they be now, he would have taken the like order with them as hee didde with Abbeyes and Monasteries. As an Heresie is bred and hatched amongst those that understands no true Religion soonest ; so, in the tender time of that sweete and gratious King Edward the sixt, these Weares had their breeding and increase.

But GOD determining his time untimely, the Weare-owners gott a descent against us: and on a sodaine wee fell into, the handes of a King of a strange Language; then wee (being Brittaines) could speake no Spanish; hee and his 60 queene 


\section{WATER-WORKES.}

queene too too much troubled in establishing their owne Religion, wee had ynough to doe to defend our bodies from Bishop Bonners Bon-fiers: and deferred all our intended Supplications to a hope-fuller time.

Our late, and blessed Soveraigne Queene Elizabeth (Englands joy, defender of the faith, \& faithful establisher of true $R e-$ ligion; (whose matchlesse Princely vertues, the world didde, and ever shal admire) yet her aged yeares troubled with a discontented warre (a) forced us to silence with many a sorrowfull heart.

Now (my Lord) the time is come to exhibite our supplications: the King of glory hath sent us his sacred servant King Fames, together with a fruitfull Queene and royall Issue, according to our owne heartes: A King that can teach Religion; a King from beyond his Cradle, and free from strange devotion; succeeding a most religious Maiden2 ueene.

(b) Now, is our time most humbly to beseech your Lordshippe (you having (a) That of Tryon.

(b) Time is now most opportune. immediate grace and favor from his Majestie, wee poore wretches not daring 


\section{WATER-WORKES.}

to speake, beeing people of the quietest and peaceablest dispositions of the Kingdome) not to neglect our Common-wealth. Remember the love your Father and Grand-father bare their-our Countrey: remember wee were their kinsmen, and servants, and of the dearest respect of any what-soever with them. Wee desire but passage of the Law of the Land; and that your Lordship wil not speak in favor of your owne Weare (O supernaturall vertue!) nor my Lord of Shrewsburies, nor any of the rest, no, nor suffer a Supersidias to land neare Chepstows-bridge least it make it shake for feare, of a second Commotion of Salmons against it. I have acquainted your Lordshipp with this matter-mechanical, \& made known unto you the raising of our Church, the planting of our Preacher, the Chappel \& Almes-house with the rest apendant : if your Lordship take but a superficial view of this giddy Invention (as some of your late servants term'd it) it wil satisfie me, it being but a particular plot, not able to be performed by any whose estate exceedes mine a million ; because the place of my Residence affords Meddow, Pasture, all 62

kinde 


\section{WATER-WORKES.}

kinde of Corne, Wood, Water near at hand; \& especially blest with such a number of Beggers as are able to undoe a Countrey. But my Lord, I doe most humbly pray, that in the reading \& viewing of my Water-workes, you will unite your heart and eyes to read respectively, for retention sake, to the $(a)$ end you may call to account, your Stewards and Survayors of your Lordshipps Mannors, Lands and Tenements; What Rivers, Brookes, Fountaines and Springes do inhabite the compasse of your command, and that your Lordshipp will spare sporting-times for some few houres, that I may give you such information, and precepts withall; that (at your pleasure) you may charracter what profit this Wattry Element will raise you, more then ever was raised.

I do not say I wil, but I could, in your Monmoth and Glamorgan-shire-countrey single out (in a short time) all the Rivers, Brookes, Fountaines and Springs which owe duty or speake well of any of your Lordshipps Lands. If my Labors bee in that manner commaunded, it will cost your Lordship Warrants for Bucks, and Letters of Priviledge, that your Tenants raise not

(a) A gainful end of painefull reading. 


\section{WATER-WORKES.}

(a) Feare of private harme makes publike hatred often to arise from long-laid rest. (a) head against mee : weening my comming to bee the overthrow of their Posterity.

I protest thats not my purpose, but to put a foote the Mistery of Winter and Sommer-drownings, to the comfort of the Countrey, and present profit of the present Inhabitants : humbly praying your Lordshipp, as you shall receive a great increase: so, you do not (according to the new fashion) by extreme racking, ransake the succeeding Issue of the faithfull Followers of your eldest Ancestors, whose old gotten-glory, at Rodes and Malta (in defence of the holy land) the Brittish Traditions and Recordes, in great aboundance, doe testifie.

I have done with my Mechanicals, and the hopefull river of Wye; only I will fixe this accidentall merryment in the Frontispice (or broad-brow) of my Preface to my Water-workes: signifying the cause of these excursions to proceed from unbeleeving creatures, possessed and pufpasted with pride and peevish opposition. An, act of Parliament will bee required for joyning of Peter-Cburch, Vow-church and Torneston, there distance beeing not 64 


\section{W ATER-WORKES.}

a mile a sunder; Turneston having onely one inhabitant to make a congregation; the living extending it selfe but unto ten pounds yearely, two of them straining them-selves to make forty in the whole.

A most miserablealowance for a Preacher and his Curate; and most miserable the time when Ignorance (out of heate of a preposterous zeale not able to render a reason of the faith they hold, nor well know whereof they do affirme) will adventure (with libellous Articles) to informe (against men conformable) a reverend father, Bishop Bennet (Bishop of the Diocesse) whose heart was prepared with all his power to the higher house of the Parliament to settle this president (viz: to unite three Parishes into one) in the Border of the principallity; Yet a new fangl'd fellow, presumed to falsefie the testimony of the Inhabitants of those three Parishes, and sought a Preaching Minister of purpose to alter the antiquity of their religion, and change the true ceremonies ther-unto incident, unto a strickt observation of quick-silver-brain'd Discipline : and cause mee to bee questioned before the Bishopp for these mis65 demeanors, 


\section{WATER-WORKES.}

demeanors, as if Heresie or Sacriledge had beene the ground. But the Bishop (most judiciously) quitte mee as no way taxable: I desir'd by Acte of Parliament to unite these Cburches into one body (being patron of two of them, the third under a prebend of the Cathedral Church:) but they wrought with the Ecclesiastical state by principall men, that an homily audibly red would be as edifiable unto the simpler sort as a presician-Sermon unto the reformed phantastiques. These troubles, the AfricanPolitician hath raised: And I feare a further mischiefe, that he will inforce those Lunatikes to stirr upp the Patron Prebend to a higher pitch; his infirmity offering nothing lesse then all the likelyhoods of discontentments. But having gotten a fee-simple in the Bishop, a free-hold in the Deane and chapter; an inheritance in the rest of the Cathedrals, we beg at your Lordshippes handes to add the Act of Parliament to put us in possession. In following which Acte, it is necessary your Lordship warrant my descent from Gladis de gam Daughter of $S$. David Gam, slaine in the vangard of the battell of Egincourt; who beeing sent by Henry the fift to discover

the 


\section{WATER-WORKES.}

the force of the French; Answered, they were a-now to be slaine, e-now to be taken prisoners, e-now to run away: which speech continues to his everlasting praise: this Gladis being mother to your Lordships Ancestors \& mine : the Earle of Pembrook, Sir Richard Herbert, Vaughan of Bradwardin, Vaughan of Hergest, \& Vaughan of Tretowr hir 5. sons al 5. brethren \& al 5. overthrown at Banbury field. Five such brethren out of one woman, the I 3 . shires of Wales hath seldom yeelded : my Lord, I am By Gladis, kin to most of the Old Nobility: which aged descent is almost worn out, yet not so worn, but either by consanguinity, or affinity, I can light on a Howard, a Herbert, a Somerset, a Carew, or a Knowles, ever ready to assist an Act of Parliament to raise a preaching Minister. These turbulents over-frighted, stir'd up the harts of the poorest people to a dangerous mislike with invective breathings, that they must goe above a mile to a sermon; that their Church would not containe the three Parishes at a Sermon-time; that it could not bee done by Law, and that forty pound was sufficient for a Preacher, and that I did it not 


\section{WATER-WORKES.}

out of zeale, but out of ambition; seeking mine owne glory \& gaine, wherin (God is my judge, my Lord) they wrong me as much as their own charitable judgements.

NOw my (honorable Lord) I come to 1 the point: to make rehearsal, and to demonstrate my under-takings; setting forth the Clothier (with his twenty broad Loomes) for the finest cloth, to be the worthiest. Ten narrow Loomes for course Wool, Flaxe, Hempe, and Hurdes. Some Fustian-loomes, with such silke-loomes as shall bee needfull: Two thousand poore Spinners, Carders, Wooll-pyckers, 2uil-winders, with the Broad and Narrow-weavers; Fifty Habitations with Shops, Chambers, Chymneys, and Cesterns for washing their hands; for severall Artificers, that neither Clothiers, Weavers, Pyckers of Woll, 2uillwinders, Spinners and Carders, shall ever lose an houres labour. No women, children, nor Prentises, shall be free of this place, but all selected Fourney-men of the best ability of body and Arte that may be had. I give fifty pound yearely and perpetually unto a Preacher; twenty 68

pound 


\section{WATER-WORKES.}

pound yearely and perpetually unto a Curate; who shall alwayes attend the Artificers, to read morning and evening prayer in their Chappell. An Almeshouse for such as (I sayd before) necessitie doth cause to for-beare their owne gettings.

Many Honorable Gentlemen finding mine ability such, as not sodenly able to raise the same : they wisht I would prepare a number of benevolent Contributers, persons of the greatest worth, best affected, and knowne to bee most comfortable to the Common-wealth : out of which Number, I doe most humbly invite your Lordship, with my Honorable Lord of Mountgomery to this benevolent preparation.

I likewise invite some venerable and reverend Bishops (my especiall good and loving Lords) the Lord Bishops of Worcester, Hereford and Gloucester.

I invite my Honourable Lords the Lord Chiefe-Fustice of England, and that worthye Lord Chiefe-Fustice of the Common-pleas: the Lord Chiefe-Baron, and my Lords the Judges in generall.

I invite the Knights of the Bathe, Knights of the Field, and Knights of 


\section{WATER-WORKES.}

GREAT BRITAINE, Maister Talbott of Grafton, Maister Sheldon of Beley, Maister Dutton of Sherborne, and Maister Harley of Brompton-brian, with all Esquires and Gentle-men of all the Counties of the kingdome.

I have seperated your Lordshipps (with the rest) from the society of the sullied leier of Subjects: so respective have I beene in the execution of this Invention.

If your Lordshipp will know what hath induced mee to these purposes: beeing over-questioned by the Tag-ragg-rable of dull-pated Ignorants; that I had protested and promised to publish my Water-workes long before this:

And ever-hoping to reduce it into that forme which might bee pleasing to all posteritie, and not quarrelled at by anye, it beeing so full of difficultie and varyetye of forme and matter.

Not possible to give it his Ornament with-out this that followes; having neyther President, nor Example, to stirre mee uppe any waye to the like labours: Ever desirous to use a correspondencie : So as a Souldier I will leave some testimonie or Relicke of that Honourable rancke 


\section{WATER-WORKES.}

wherein I had my breeding: and end my dayes with a Souldier-like fare-well.

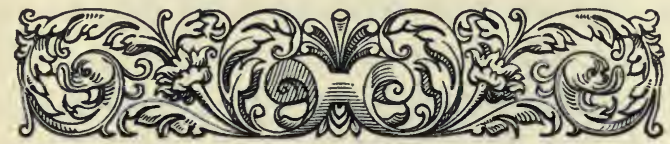

BEeing one of hir Majesties Captaines, raisd in eighty-eight, having my directions from my Honourable LORD and Maister your Father: I have spent that small Talent \& skill. Never curious in concealing from my Lieutenant, Ancient, Serjant, Corporalls, and Drumme, the worthynesse of the warre: unto which I am much inclin'd.

Most humblye beseeching your Lordshipp, if you heare any say, I am fantasticall, say you (my deere LORD) I am but curious; so excuse mine Imperfections the best you may, and I will ever honour you.

The time is spent, and I must spende some time with the Printer: and a little more in sorting, couching, and planting my dyning-roome, free from all disorder. 


\section{WA TER-WORKES.}

In what manner my Table shall be furnished; What attendance the Mechanicall Artificers shall performe; how industrious my Ancient and Serjeant shall bee in preparing all these Artificers for his Majesties service, into what place it shall please his Highnesse to command them.

Now(my Lord)I end with this materiall circumstance beeing extracted out of mine owne meanes. I signified in mine Epistle to your Lordshipp, A dining-roome to entertaine a world of worthy benevolent Contributers: The Table perpetually furnished to entertaine forty of those Contributers dayly in expectancy; A hundred Artificers subject to the Service of the Table: Twenty-five attending at Dinner, and twenty-five at supper: fifty more on the morrow: and so the hundred Artificers shall attend the Table in this manner Dayly and Perpetually.

In recompence whereof they receive the benefit of the Reversion with all the comfort I can afford them.

All the Artificers to attend the Preacher to Sermon and home againe. The Visitor of the Negligencers Attendant to informe their misdemenors to the chiefe of the 


\section{WATER-WORKES.}

Company, if there beecause that no common Swearer, Drunkard nor Swaggerer shall live within the limits of my allowance. His first offence warned, the second punished, the third discharged for ever from the place: Every Artificer shall unto every Contributor (at their comming thether) humble them-selves with (all respective obedience) acknowledging them by word and deed to be the Founders of their welldoing, and happy Common-wealth.

The Dining-roome wainscoted, and fairly hang'd with Arras.

Touching the Fare to bee served to the Table dayly and perpetually, forty full dishes of variety of meats; with a Pasty of Venison to Dinner, and another to supper, when they are in season.

A Sentinell sett from ten to eleven in a Turret, for discovery, to see what Contributer comes: If a Foot-man dwelling in the neighbourhood; he gives the Larum by the toule of a Bell, signifying him to bee a Foot-man; which heard, then the Drumme soundes. If a Horse-man, by the Larum hee signifies him to bee a Horseman, and then the Trumpet soundes. And upon their comming into the Dining$\mathrm{F}$ 


\section{WATER-WORKES.}

roome, All Officers of the company intertaine the Contributers with all joy and merryment: the wind Instrument, with all sortes of Musicke plaies Dinner and Supper: and to adde all the comfortable contentment to all Contributers, from Bartholomew day to Mid-may.

The Groome of the Chamber shall at his perill prepare a good fire with $A$ she, Hawthorne, and Char-cole.

My LORD, that honourable and most worthy Judge the Lord Chiefe Justice Poppham hearing of my Drownings; said Cousin, how dost thou drowne? I told him by helpe of a River or Brooke; by Weare and sluce to take part, or all, into my Trench-royall. Whats thy Trench-royall (saith hee?)

The Trenchroyall is a Cesterne that serves al offices in a Noblemans house.
As a Cesterne in your Lordshipps house, that serves all Offices: My Trench-royal serves my Counter-Trenches; my DefendingTrenches, my Topping or Braving-Trenches, my Winter and Sommer-Trenches; my Double and Treble-trenches; a traversing trench with a point; And my Everlastingtrench, with other troublesome trenches, which in my Mapp I wil more exactly demonstrate. 


\section{W ATER-WORKES.}

The good Lord hearing all these wordes, (able to raise a Spirit) sayd: Cousin art thou out of thy witts?

My Lord for distinction sake (said I) I must give them significant names, such as my servants attending my Winter and Sommer-Drownings may understand to execute my commands.

So, my Lord, I having given satisfaction to the honourable person, I will make it most plainly appeare to your Lordshippe how fecible this Worke is: that all Cynick-Doggs or Lamb-biters, may with shame be silenced, and their foule Mouthes muzled.

It is yet wondered at, by almost all, how a particular and private Gentleman should bee able to bring all this to passe.

But my good Lord (on my behalf) I humbly pray you to pray all of the better sort, to bee sparing of their censures herein; for artlesse-Aimes seldome hitts the marke.

I would that no man should say, I doe To speake what we know not, is to think what we should not.

it out of ambition or other sinister respect: for the Rule of Charity is: in cases doubtfull, wee should judge the best.

But if any (notwithstanding) should bee so injurious to say so, then (my 


\section{WATER-WORKES.}

LORD) they may say the Clothier; the habitation for Artificers, the Chappell, and Preacher, Curate, Almes-house; My Table for the benefit of poore Artificers, and whatsoever else is good (yea a Commongood) is out of ambition.

I hope (my good Lord) I shall heare no more of such Objections; if I doe, though I am no Poet yet I can make Ballads, To the tune of up-tayls-all: For Ile lash them Ifayth with Rimes that shall make it rancle where they fall.

But to take away the wonder of the World, and to give satis-faction to the envious-unsatisfied.

This I mince thus for illdigesting stomacks.
A just excuse.
I can keepe three hundred Kine, three hundred young Cattell, three thousand Sheepe, all these Winter and Sommer : Having besides ten Plough-Land, all hard at hand ; foure Milles as neare, and within two mile of the place Tymber sufficient for all my Buildings. And Fire-wood ynough for all the Artificers, the Inholder and the rest; Wall-stone, Tyle, Lime and Bricke, as necessary as any man living.

My good LORD, I doe not thus Inventory my Estate, and paint forth the 76

Particulers, 


\section{WATER-WORKES.}

Particulers, as if I were to sell it by the Drumme; or as looking thereon with Vaine-gloryous Eyes. No, no, my good LORD, nothing lesse (for there is no such cause, I am the more sorry). But I doe it (perforce) to give the doubtfull Inquisitor satisfaction for the setling of his beleefe herein, That I attempt nothing with out the limmitts of mine owne strength.

But now your Lordshippe shall heare an end of the Wonder. All men wil confesse, three hundred Kine wil raise, Braunes, Bacons, Porks, Piggs, Geese, Turkeis, Capons, Hens, Chickens, Ducks, $\&$ the like. They wil confes ten Plowland in severall places, all with-in a myle, with my Tithe-barnes, will do the like.

They will confesse my foure Milles beeing within a slight shoote one of another, will doe the like: They will confesse my Brew-house, my Backe-house, my Kitchin, my Beare-seller, my Shambles; and the water from my Uting-vats will doe the like. Besides in a Maste-yeare I can feed a world of Hogges.

Your Lordship sees I am forc'd to doe, and over-doe, as one that must doe All, else nothing will bee done: I thinke I 


\section{WATER-WORKES.}

What benefit can be raised. have besturd my selfe pritty well, to make the whole world wonder at mee.

Your Lordshipp shall now see what benefit I receive for the perpetuall continuance of this Table.

The Butter and Cheese of my three hundred Kine, I sell, and furnish the Clothyer, his Broade-weavers, Spinners, Carders \& the rest; with all the Mechanicalls there-with. The Corne of ten Plowlands, Wheate, Rye, \& Malt made in my own Killing; I grinde at my owne Milles; Bak'd, \& Brewed in my Bake-house and Brew-house; and sold to the foresaid persons : My Wooll, my Muttons, Lambes, and culld-sheepe, of my three thousand I sell to the sayde persons: I sell yearely one hundred of my eldest Oxen, Kine, and my cul'd young Cattell fatte to the persons aforesaid: I finde all Artificers; and Inkeepers wood, which will bee ten times more profitable unto me then now. Let Men judge what benefit I may make of my Brew-house, and what of my Bakehouse, what of my shambles, my Haye \& Provender; my Chandlers-shopp, my Barke unto the Tanner: to whom I sell all my Hides; the Glover hath all my Pelts: what 78 provision 


\section{WATER-WORKES.}

provision my owne estate will not affoord, the neighbourhood can provide it, that neither want nor scarsitie shall afflict any of his Majesties servants and subjects.

My good Lord, let it not seeme irksome to you, nor cloy your dainty eare, that thus I belabour your attention with repetition of these countrey-commodities, and common-wealths Requisites; so to season your courtly pleasures, as sharpe sawce doth sweete meates, but when you bend your regarde to these things (as I doubt not but you will: For active witte in short time turnes to working wisdome:) The worlds observation will then know, you waxe ripe for the highest imployments: For it strongly argues youth is then well mellowed, when it begins to looke into these necessaries for mans life with Ages eyes. Pleasures, that tickle our sences, make us but spoile Pretioustime; while they betray our Reason, that should rule rebellious affections that ought to obey. The sooner these enemies, to mans dignity, are shaken off from the Minde, the sooner will the Minde advance the Body to dignity.

It is a glorious (how ever troublesome) 


\section{WATER-WORKES.}

thing to have a chiefe Oare in the Shipp of a well-governd state. The benefit of life in great men cannot be better imployde then to the benefit of good men. For the Back and Belly is Natures chiefe care; these beeing provided for, shee sweetly takes repose. What is over \& beside, is for Ornament, which shee wants not: for pompe which shee requires not: or for pleasure, which if she wanted, shee would the more abound in all goodnesse.

Now, (my good Lord) these Indevoures and Workes of mine (tending to thee full supply of the Back and Bellyes wants) are to be heedfully respected in their particulers, by you that one day may have this care cast upon you, by God, King, \& Countrey, to see to the necessities of All, while you consult but with a Few. Its merry in hall, when beards wagge all, (saith the old Proverbe). And it's a merry Weale-publick, where ever-enough is as good as a feast, suffizing all by good government. 


\section{WATER-WORKES.}

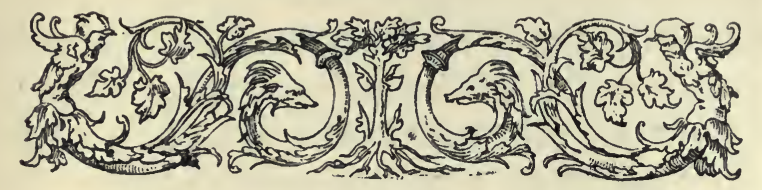

\section{The manner of my Drownings.}

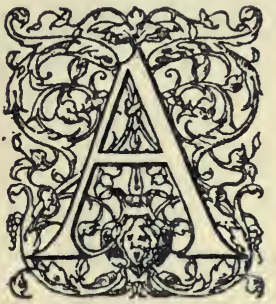

Fter I had spent some yeares in Queene Elizabeths Court, and saw the greatnes and glory therof under the command of Mistres Blanch Parry (an honorable \& Vertuous

Gentlewoman, my Aunt and Mistresse) my spirite beeing too tender to indure the bitternesse of her humor; I was by her carefull (though crabbed austerity) forced unto the Irish wars, where I continued three or foure yeares some-times twist deep in that country-water: \& what with long fasting and ill diet, I was possessed with the Country-disease : the extremity whereof hasted mee to returne to 


\section{W ATER-WORKES.}

my Fathers home in the County of Heref. for recovery of my health: which within sixe months I obteined. After it pleased GOD to give mee recovery, I resolved for the Lowe-countrey-warres againe : and having begun my journey thetherward, I happened on a Country-Gentlewoman, who was seized of a Mannor, and over-shot Mill: which converted all my martiall endevours and hopes of honor, to these country-labours : Having sojourn'd two yeares in my Fathers house, wearied in doing nothing, and fearing my fortunes had beene over-throwne in putting by my Martiall occupation; I began to expostulate with my selfe what was best to be done to preserve my reputation with my martiall companions, and with-all to give contentment to my vertuous and loving wife. And while I was to settle a resolution, comparing these desires together, my Wives importunity caused mee to quitt their ordinary familiarity, yet with limitation; at such times as conveniency might afforde.

This restraint of hers, drewe mee to the attendance of home-labours; who prayed mee with-all in my walkes abroad, to have 82

an 


\section{WATER-WORKES.}

an eye to her Millers true dealing. I prayed her to put over that service to some servant of hers: for of all trades I had least confidence in their truth: and therefore required the more paines to be taken in watching their water, \& looking to their fingers, which I was loth to undertake: not-with-standing, (upon better consideration, least shee should have held me carelesse of her good, and so ill deserve her love) I obeyed her will, as many doe, and many miseries do ensew thereby: So, in the month of March, falling (with the streame) to the milne-ward within my Meade (with no desire (I protest) to fashion or forme Husbandry) I happened to finde a Mole or Wants nest, raised on the brim of the Brooke, like a great hillocke; from which nest or hillocke, there issued a little streame of water, (drawne by the working of the Wante (downe a shelving or descending ground, one pase broad, and some twenty in length.

The running of which little Streame, did, (at that time) wonderfully content mee, seeing it pleasing Greene ; and that other on both sides full of Mosse, and Hide-bound for want of water. This

The first cause that the work was undertaken. 


\section{W ATER-W ORKES.}

was the first cause I under-tooke the drowning of grounds.

Now, to proceede to the execution of my worke (beeing perswaded of the excellencie of the water) I examined how many foote-fall the Brooke yeelded, from my Mill to the upper-most part of my grounds, beeing in length a measured Mile.

There laye of old Meadow-ground thirty acres over-worne with age, and heavily laden with Mosse, Corwslips, and much other imperfit grasse, betwixt my Millstreame, and the maine River; which (with two shillings cost) my granfather, and his gransire, with the rest, might have drown'd at their pleasures: But from the beginning, never any thing was done, that either tradition or record, could witnesse, or any other testimonie.

Having vewed the convenientest place, the upper-most part of my ground would afforde for placing a Commanding-Weare, or Sluce, I espied divers Water-falls on my neighbours grounds, higher then mine' by seaven or eight foote; which gave me greater advantage for drowning of more ground, then I was (of my owne 


\section{W ATER-WORKES.}

power) able to doe. I acquainted them with my purpose: the one (being a Gentleman of worth and good nature) gave mee leave to plant the one end of my Weare on his side the River: the other (my Tenant) beeing very aged and simple) (by no persuasion I could use) would yeeld his consent : aledging it would marre his ground: yea, some-times his Apple-trees : and men tolde him water would raise the Rush, and kill his Cowslipps, which was the cheefest Flower that his Daughters had, (beeing many) to tricke the May-pole withall. All which with silence I past over for a time, knowing his simplicity to exceed his discretion; yet in the end I re-enforc'd my persuations, and tolde him (next unto the King) I was to bee obeyed in matters reasonable : and that it became him not to provoke his Land-lord; nor to stand at the staffes end with his Commander. Yet these Buggs-words would not moove him. Then gave I a fresh charge, and to draw him on with a Baite which hee would soone bite at, tould him I had a Meddow-plott in his neighbourhood, worth forty pound, which I would part with on 


\section{W A TER-W ORKES.}

For no simple fee.

reasonable termes: but before I could make him beleeve hee was a foole, he gott the Fee-simple thereof. Which President doth falsifie the old-said-Saw, Thou art an old doting foole. After I had wrought this farre, I caused my servant (a Foyner) to make a levell to discover what quantitie of ground I might, (from the entry of the Water) obtaine : allowing his dubiingcourse, compassing Hills to cary it plym or even: which fell out to bee some three hundred Acres. After I had plimmed it upon a true Levell, I be-tooke my selfe to the favour of my Tenants, Friends and Neighbours, in running my maine-trench (which I call my Trenchroyall) I call it so, because I have within the contents of my worke, Counter-trenches, defending-trenches, topping, or bravingtrenches, Winter and Summer-trenches, double and treble-trenches, a traversing trench with a point, and an ever-lasting trench, with other troublesome-trenches: which in my Map I will more lively expresse.

When the Inhabitants of the country wherin I inhabit, (namely the GoldenValley) saw I had begun some part of 86 


\section{WATER-WOR KES.}

my worke, they summoned a consultation against mee, and my man Fohn the levellour : saying our wittes were in our hands, and not in our heads: so, we both for three or foure yeares, laye levell to the whole Country-censure for such Enginors as their fore-fathers heard not of, nor they well able to endure with-out merryment.

When my labours tooke beginning, they became subject to discourse : Diverse Gentlemen with others, inquired from whence I had my Examples; and where I saw any such worke? I could not answere them but with an other question : namely, where sawe you any such? They said, no where : Truly nor I.

In the running and casting of my Trench-royall, though it were leveld from the beginning to the end, upon the face of the ground, yet in the bottome I did likewise levell it to avoyde error.

For the Breadth and Depth, my proporcion is ten foote broad, and foure foote deep; unlesse in the beginning, to fetch the water to my drowning-grounds, I rann it some halfe mile, eight foot deepe; and in some places sixtenne-foote

broad. 
Ignorants praise good endings, but doubt, or dispraise their beginnings.

\section{WATER-WORKES.}

broad. Al the rest of the Course, for two miles and a halfe in length, according to my former proportion.

When my Worke began, in the Eye of the Countrey, to carry a shew of profit, it pleased many (out of their courtesie) to give it commendations, and to applaud the Invention.

The Joyner hearing the commendations to bee generall, and hee the Leveller (which was (he thought) the cheefe Agent in the Action) there grew a brabble betwixt us. Hee began to insult and arrogate as a Coadjutor, by reason of his levelling, and desired hee might bee signified a principall party to the Invention.

I bad him have patience, the Invention was mine, together with the dignity: and told him withal the ambition of soldiers would not indure society with men of Mechanicall trades: I only imploy'd his hand, and not his head.

So having compounded the brabble betweene us, I fell into the handes of an unskilfull Carpenter, in planting my commaunding Weare or Scluce, crosse the maine River. 


\section{W A TER-WORKES.}

Hee gave mee such assurance for the safe continuance thereof; that hee undertooke to maintaine it with twelve pence a yeare, during his life.

After hee had prepared it ready for the foundation, hee planted some thousand stakes in the bottom of the Brooke to carry the maine Syll. When the Syll was lodged uppon the Pile of Stakes, I began to suspect the foundation, and told him a great part of the water would undermine the Syll, and that I should hardly indure the want therof at my Drowning-times; especially in Sommer.

Hee grew teasty, hott, and peremptory; and sayd it was not the Maisters manner to controule; but, to examine : and that all his Water-workes were according to the Venetian foundation, built altogether uppon Piles: but the Venetian-fashion forced mee to want water ten yeares space, which was out of my way two thousand poundes.

The reason was this; the water undermining the Syll, it forced the Earth beyond the postes, which were placed in the firme ground; and having gotten the upper hand of the main-Land it could not bee holp untill the Sylle were rais'd G 


\section{W A TER-WORKES.}

againe. I hadde a continual purpose to re-edifie it, but that I was interupted by the ordinary course of Processe out of the honorable Courts of Starre-chamber, Chancery, and Wardes; the last of the three bredd more white haires in my head in one yeare, then all my Wetshodwater-workes did in sixteene: Not that I had cause to complaine of Injustice; but, because I understood not the course of the Courts, being pusled with an old Feodary, and a foolish Escheter, (the life and death of my cause resting in their mercy.) Twelve Jurors who passed against mee, lawe, equity, and conscience: Upon which Verdit, I was, by Injunction, commanded to deliver the body of a $W$ arde I had in keeping, which I refused to doe: It happened my Councell found Error in the Office, and over-threwe the former proceedings, which was the overthrowe of my Water-workes for five yeares space.

The over-throwne-Office was a stolne Office, and found before I had notice of it. But beeing over-throwne, matter of greater consequence followed.

The 2ueenes Atturney commanded the 90 Feodary, 


\section{W A TER-W O RKES.}

Feodary, who had gotten a grant of the Ward, to exhibite enformation against mee in his name: wee had Commission upon Commission: wee indured heavye and chargeable examinations.

Uppon which Examinations I had a Hearing in that Honourable Courte; and though it could not passe against me, yet it passed not with mee. One other Commission came downe, A Jury impanalled, Witnesses re-examined. That Jury found with mee, \& (in my conscience) not one of the number understood his evidence: All which I shew to satisfie the Inquisitor, why so long I neglected my begunne Water-workes. When the Escheator, Feodary, Commissioners, and Furors hadde putt their hands \& seales to the Office, I prepared my self to my forsaken Waterworks; having left my wanton Ward in London in the custody of a Precisian or Puritan-Taylor, who would not indure to heare one of his servants Sweare by the Crosse of his Sheares, hee was so full of Sanctity in deceipt. But the first newes I heard, hee marryed my Welch Neece to his English Nepherw; and at my returne I was driven to take his word that hee

(a) Holy fraud is the falsest fraud. 


\section{WATER-WORKES.}

was neyther privy to the contract, nor the marriage.

I desir'd but his oth for my satisfaction; hee badde mee have patience, it was not his fashion to forsweare him-selfe. Thus hoping I had beene quit of the cause, I prayed recompence of the Offender; But within sixe months a new Commission came downe; and a new Office found against mee : which manner of proceeding ( $\mathrm{I}$ thinke) was able to breede white hayres in a Brittaines beard.

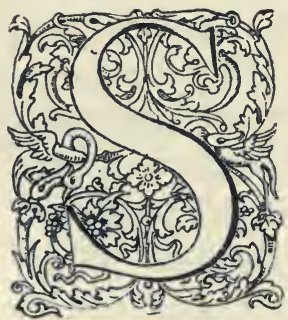

INCE THE FIRST Time I undertooke the drowning of my groundes, I (as carefully as I could) sought to better my understanding by other mens labours: yet in the whole Kingdom I never found, nor heard of a work worthy observation: Having so many Rivers, Brooks, Fountaines and Springs, which run idely unto the Sea: without Weare, Sluce, stay, stanke or dam, to turne some part of them upon grounds that need them, or to containe the substance 


\section{W ATER-W ORKES.}

of plow'd lands and dunghils, which by violent showers washe away, and runnes ranging by those grounds that hunger and thirst for want of moisture. Our HusAs good no running, as running for no good. bandmen brag of raising Corne: How? out of ther painfull labours: but (if they want compost) their increase is but barren, and for ought I have seene (except some few Soiles which yeeld plenty of Hay, by often overflowing of fresh Rivers, or the Tide staying uppon them as it were by damm) those fresh-waters yeeld their increase by nature, without industry. I would aske how many Shires bee in England, and in every Shire how many Rivers, Brooks, Fountaines, and Springes? If the number be great, I wou'd know how they be imployed, and what our Corne-maisters (which carry the reputation for good husbandry) will say to it? They will say (peradventure) and so will all Husband-men (without peradventure) it is easie to raise Corne with store of Compost: but (wanting Hay ;) I would learne how compost may bee raised? The question betweene errable converted to medow, and errable not converted, wil be this : some will say, there is no reason 


\section{W ATER-WORKES.}

to put good errable to bad pasture. So say I too. Others will say, ordinary errable exceedes ordinary Pasture. It may bee true: but I speake of good errable appointed to bee drowned: I will give no estimat of English Errable; scituate neare London or Haven Townes, or to places more vendible then the country wherein I inhabite. Yet this will I exemplifie out of my experience, if the Principality were duly imploied, \& each acre handled according to some plots begun, I would hope to live to see Wales called the Garden of England : for our Welsh mountains yeeld infinit Fountains \& Springs, the Grounds Fearny \& broomy, it being of as excellent a temper to intertaine water as heart can wish; unlesse wee flye to the maine Sandy-grounds, which are but sparingly found in Wales; the Country lying in a colde quarter of no hotte Climate.

(a) At what time, with what water, \& how long you ought to drowne your Grounds.

Now, to speake of drowning, (a) at what time of the yeare, with what water, how long it may continue on the ground, and what effect it will worke, you shall have all I know to the uttermost; at least if I remember all. 


\section{W ATER-WOR KES.}

Now, fixing your fancy on this Misterie, you must pry into every Fallow-field, Dung-hil, and Water-course in your neighbourhood: then compare the quantity of ground unto the quantity of water you can draw unto it, and if you find water ynough to answer your desire, then in the beginning of your ground, plant your weare or scluce in height levell with the Bankes, or exceeding it one foote (or there aboutes) ore-thwart the River or Brooke : and carry your Trench-Royall (which is your grandmaister-Trench) so farre as your ground extendes plimm or levell: that from the mouth of your Weare, or Scluce, to the end of the ditch or trench, your water may flow backe againe over your scluce into the River or brooke. In so doing, you have a full command forward and backward (without any descent) to drowne at your pleasure: though your trench royall rise in the end twenty, or forty foote from the mouth of the scluce.

Having prepared your drowning-course, bee very $(a)$ carefull that all your ground subject to the same (whether Medow, Pasture, or Errable) bee as plaine as any garden-plott. If you leave any forrow,

(a) Looke well to the levelling of the grounds that are to be drowned. 


\section{W ATER-W ORKES.}

reane, or slade, unlevelled, you shall finde that forrow, reane, or slade, will receive the most part of your water idely: which otherwise would disperce over the whole; and comber you with the care of new plowing it to make it the more plaine: which will hinder you two or three yeares at the least. Having made your weare or scluce, your Drowning-course or Trench, your ground levelled or plimmed, then followes your attendance: in flood-times see you suffer not your floud-water by negligence to passe away into the brooke, river \& sea; but by your sluce, commaund it to your grounds; and continue it playing theron so long as it appeares muddy: and finding the substance decaying (from a fat floud unto cleare water) take upp your sluce or floud-gates, and suffer the cleare water to have his course unto the maine brook or river again, untill new or fresh flouds appeare; and still as it riseth muddy, imploy it on your grounds during the winter-season. When you have spent the winter in muddy-floods, and your grounds seasoned by sucking the substance of each fallow, and dung-hill : be sure, in the beginning of March, to 96

cleare 


\section{WATER-WORKES.}

cleare your ground of cold water ; and keepe it as dry, as a child under the hands of a dainty Nurce; that the continuance of cold water in the body of your ground in the spring, breed neither Rush, Boult, nor Spierygrasse: but grasse much more profitable, thick, long, and fine; voyde of all Mosse, Hard-heads, Corv-slips, or any weede what-so-ever.

Observe respectively your soyle, whether clay, or sand: for, sandy-grounds will endure tenne times more water (being naturally hotte) then the cold clay: yet some washers of grounds, (in their owne conceits) will imagine it's behoovefull to turne the water at all times on their lands; or as long as they (in their discretion) thinke good. But so may (with indiscretion) surfeit a clay ground with a drunken-dropsie, as all the Phisitions in the neighbourhood, with all their visitations, will hardly heale in two yeares space. Having sufficiently sped your clay-ground in the drowning-time, (I meane Winter) you may (by negligence, or ignorance) suffer colde water, in the heate of Summer, to coole your ground so much, that the vitall spirits will bee decayed : and that moisture

In the beginning of March cleere yourgrounds from cold cleare-water.
The best husbands or husbandmen. 


\section{W ATER-WORKES.}

moisture having gotten the upper-hand, the Sunne workes, out of that drunkendropsie ground, the Rush, and all other ill pleasing stuffe, and unprofitable trash. I said in the Spring, you must keepe your grounds drye. If March follow his kinde, and Aprill drye, overflowe it with Clearewater, that it receive no drought: for, all men know, if the Spring bee drye in May, it's two to one Haye never goes a begging.

Amongst other things, an olde Drunkard once warned mee, I should not suffer the roofe of my mouth to bee drye: yet I never followed his example: I remember the cup was never from his mouth, and hee in the end dyed of a dropsie: so, in claye-ground, in the heate of Summer, drowne it moderately: and, (it beeing once sufficiently seasoned in May) you need not drowne it untill a day, two or three before you mowe. At which time you provide for mowing, if sufficient showers, have not quallified the drought of your ground; let downe your sluce into your trench-royall, that there-by you may command so much water to serve your turne as you desire. Which Trench- 


\section{WATER-W ORKES.}

royall running on the plimme or levell, suffer it to discend, where you meane first to mowe, and you shall finde this manner of drowning in the morning of your mowing so profitable and good, that commonly you gaine ten or twelve dayes advantage in growing: for, drowning before mowing a day, two, or three, so supples the ground that it doth most sweetly release the roote of every particuler grasse, although the Sunne bee never so extreame hotte: otherwise, if you drowne not before you mowe: you mow one day, you ted an other, you spend one in gathering it into windecockes: and with-all, stand upon the uncertainty of the weather, whether you dare adventer to breake your cockes or no. Beeing broken, they must have a dryingtime before they can bee put into greater cockes; and then opening them againe into the last and greatest, by tedding, gathering, cocking, recocking, and treble-cocking, your haye continuing above a weeke on the ground; the ground being bare, and induring the heate of the Sunne at Mid-summer (in the hottest time) it doth so drye and parch the ground, that if the

How profitable to drowne a little before mowing. 
Signes

of well seasoned grounds.

\section{W ATER-WORKES.}

heavens yeeld not more raine then is necessary for a Common-wealth, you latermathes will proove unprofitable: where drowning before mowing, will make good a second mowing: and in walking over grounds I will tread as on Velvet, or a Turkey Carpet.

This Drowning before Mowing, puts wormes to execution, or forceth them to flye from their habitation: for sure I am that that ground will not bee troubled with them untill they raise a new generation; and that cannot well bee in those grounds with-out great store of heate? which if it happen, to what end serves your water, but to season the ground againe. The Summer may bee so extreamly hotte as the fervencie thereof may force you to double or trebble drowning; yet I would wish all those that have not the true understanding and use of the water (before they put this in execution) to enquire where any such worke is; and having found the place, to observe the Weare that commands the River', and to note the length of the trench-royall, and plimme thereof: what stankes, lists, or trenches bee within the 


\section{W ATER-WORKR}

contents of the grounds: and, having found your drowning, and fore-recited trenches, observe what height every stanke or damme is : and if you can see the flouds playing against the damme, your experience in beholding it goeth farre beyond mine.

I will not forgett the two-foote-trench, topping your Maine-river, with-in foure, or five foote from the Banke, as occasion is offered. The use of which Trench so neere the River, many may wonder at (as many have done) why it should bee drawne so neare the maine-river it being but two foote broad and one foote deepe.

I know not how all Rivers and Brookes runne else-where, but in that which I labour, the ground is much higher on the River side, then the maine-flatt-bottome, and, where by sluce I drowne some thirty Acars upon a reasonable levell; yet upon the River side the height is such, as my sluce will doe no good, if I suffer the water to descend into the flat bottome, not taking the advantage in the beginning of my Topping-trench.

If part of your ground bee drownd, and some part forgotten, there is a fault somewhere; either by ignorance, or negligence,

A fault to drowne some, and to leave some of the same ground undrowned. 


\section{WATER-WORKES.}

or both: but to helpe both; I pray you forgett not to runne this trench, topping and braving your River, that in the Winter, you drowne that with the rest.

In Summer, your commaund is more absolute, it beeing shelving or descending to your flatt-bottome-ground; you may with a boord of two foote broad, and one foote deepe, stay that water, and suffer it to play upon the face of the ground, halfe a quarter of an houre, or little more, untill it meete with your flatt bottome.

And thus you may handle the braveingtrenche, by drowning the shelving ground every morning in the heate of Summer, before and after mowing; so long as you finde the Sunne forceable.

Your flatt-bottom-ground, beeing, in the heate of Summer, drownd, suffer the water from your shelving or descending Trenche, but to kisse the hand or foote of the same : for it beeing claye, and once drowned, before mowing in the extreame heate, it will not endure a second drowning with-out danger: unlesse the heate doe so extreamlye increase, that one extremitie must incounter another.

So, you may fall to double drowning IO2 


\section{W ATER-WORKES.}

(if there bee cause) which you shall easilye finde by trying the temper of your ground, thus :

If a riding rodde (beeing some-what You must double drown in the summer if there be stiffe) will enter into the ground two foote deepe or more, it sheweth it hath had moysture sufficient by the former drowning;

If the rodde will not enter in, but by difficultie, or forceable handling, you may judge it to bee over-dryed : And in this manner make tryall in what state your ground stands, whether too drye, or sufficiently seasoned.

If to drye, give it watry sustenance to nourish and revive the dying roote: and, having satisfied your ground, suffer your two-foote-trench to have a continuall course of water, Winter and Summer, for these reasons following: That is to say; In Summer, when you would drowne, your trench beeing full, you neede not staye the letting downe of a sluce out of the maine River: for, so shall you staye the time untill your water rise to the highest of your sluce; and beeing risen, must have a time to come into your two-foote-trench, to execute what you would have done: where cause. 


\section{WATER-WORKES.}

otherwise, your trench beeing continually full, you may (as I sayd) appoint your servant with a boord to stay or stoppe the trench; and so from place to place, drowne your shelving or descending ground from the beginning of your trench, to the end thereof both daylye and hourely.

This Topping or Braving-trench; hath this excellencie with-all, that it running

Wants will not worke in water, nor where it soakes. continually in the trench, frees your grounds from Moules or Wants: for they will not worke in water.

If they desire to fall into the midst of your other Meades, they must undermine the Trench, swimme the Trench, or some way shuffle over.

If they do; see their danger: they being once found to worke in the belly of your Mead, they bee subject to death, by your commanding the water from your two-foote-trench to descend on the rereward ; the sodaine course whereof comes so fast uppon them, and they wanting foot-manshippe to rescue their lives, are overtaken, to their utter overthrow.

Suffer not one Moule, or Want to live betweene your two-foote-trench and the maine River, which is not far distant.

$$
\mathrm{IO}_{4}
$$

They 


\section{WATER-WORKES.}

They having no great scope to worke, will so undermine from the brink of the maine River to the brimm of your Trench, that in your drowning-time, in the heate of Sommer, you shall finde so many Springs from their working-holes into the River, which if you stop not, with great care, in finding the places of breach, the most part of your water will runne into the River idely.

To speake of the braving-trench: Beginning at the Commanding-weare, or Scluce, it works this effect: if the violence of the flood should bee such, as uppon a sodaine, your hay at Midsomer should be drowned by over-flowing the banke, or in your After-math-time the like should happen, it is at your choice whether you will suffer that inconvenience or no: for the Earth taken out of your two-footeTrench, beeing throwne on the one side of the same, raiseth the Ground higher then that beyond the River, by two foote at the least: which forceth the Floud altogether, on the other side, and keeps your Hay and After-math ever in safety. This Topping or Braving-Trench must runne to the lower part of your Groundes,

$\mathrm{H}$ IO5 as

The Offices of the Braving Trench. 


\section{WATER-WORKES.}

as a hand-maid to the maine River, to attend your pleasure Winter and Sommer.

I would have you suffer some Water to runne therein continually: Which continuall running will scowre your Trench, and lett all filth from falling therein: and if it should fall you are driven to often cleansing it.

Beeing sometimes with Water and sometimes without, the Mole or Want instantly possesseth the same, and workes along the Trench an Arrow shoote in length: And it beeing so exceeding moist, makes many Holes, cleane through into the maine River, and at your next turning in of the Water will it issue out at every particular Hole; and your Trench, beeing but foure or five foote from the River, the Ground beeing too much moistned, falleth or calveth downe into the same.

It's not sufficient when you have conveyed your Water from your first Sluce into the Body of your ground or bravingtrench, then to give it liberty to runne a-heade: for so will it fall into the lowest part; but you must govern and lead it, beginning at the highest of the ground,

$$
\text { I06 }
$$

unto 


\section{W ATER-WORKES.}

unto rising places, and so suffer it to descend against some Stanke, or Damme; which you must raise as occasion shall bee offered : As this; if your ground falls so much that the course of the water offers to runne into the maine River againe, before you have done with it: Raise a Stanke a foote, two, three, foure, or five, or so many as may stay it to the height you desire, and force the same against the Ground unto your lower Grounds; and so continue it playing from Stanke, to Stanke, from the beginning to the end thereof.

So, shall you bee sure by raising of these Stankes or Damms, to stay all the substance of substantiall Waters which is forced by your Weares, or Sluces, into the body of your ground, there to remaine : where if there were no Stanke or Dammne, the water (running headlong into the lowest part) carrieth the substance so mainly forward, that little or nothing at all wil be left upon the face of the ground to nourish the same.

Now to furnish you with the present understanding, how to make your Flanks or Dams; in what place, and how farre 107 you

How to governe and lead the Water from your braving Trench over your grounds.
How to make your Stanks or Damms. 


\section{WATER-WORKES.}

you would have it drowned; repaire into the lowest part in the beginning of your uppermost ground; where if you desire to pound it to such a hight; pitch your Levell there; which Levell (or Instrument) I will make knowne more familarly unto you in the Mapp of my Worke, (which you shall find in this booke incerted) and commaund your servant to hold some staffe with a paper bound about, some two inches broad: and looke through your Levell from the lowest part of your Ground, unto your desired place. In this manner your Levell will assure you how to cast your ground to an inch.

And when you have truly learned to Level, which in one hour I will undertake to teach you, you may range over the Kingdome as principall survayors of Rivers, Brookes, Fountaines, and Springs, and accuse the best wits of the greatest negligence, in matter of the greatest Common-wealth.

Waterworks, be most chargeable to the Ignorant.

It hath beene sayd by some, Waterworkes be chargeable and dangerous. They'bee so; for if you adventure to commaund maine Rivers, as Thames, Severne, and the like: you may judge I08 with 


\section{WATER-WORKES.}

with what difficulty it will bee done. In their beginnings Breadth and Depth is increased by a number of small Brookes, the Commaund therof goeth beyond the estates of the most men : yet there is no River in the Realme (be it Thames, or Severn) where there is any descent, but that I wil steale, by Counter-trench (when the muddy floud is level with the bank) so much water as I desire.

If you aske mee how broad, and deepe the Trench must be: I would know what quantity of ground you have to drowne: if much, your Trench must be the wider and deeper. I need not putt you in minde to raise a sluce on the mouth of your trench; if you do it not, common inconvenience will compell you.

You will never drowne so oft as the floud riseth to the height of the banke, because of your Hay \& after-math in Sommer: Therfore as I sayd, you will be compelled for your safety-sake to Sluce your trench.

As your Trench-royall feedes your shelving-groundes and falls into the flatbottome, and rising to the height of your first, second and third stanke, with the

Your Trench must be made great or small according to the quantity of ground you are to drown. 


\section{WATER-WORKES.}

rest; take heed the water exceed not the height of any of your stanks or damms a hayrs-breadth: for the force of the water and violence of the winde in a furious tempest, will over-throw it, as if the Canon plaid against it.

I have forborne to speake of my StankRoyall, which is of purpose prepared to intertaine the Trench-royall: which Trenchroyall, in the continuance of his running, undertakes the safe conduct of three Brookes and some Springes withall to the Rendez-vous or place of generall Consultation, where their imployment shall be; whether against the Stanke-royall, the Maine-stankes, the Counter-Trench, or the rest. But indeed the Stanke-royall intertaines all commers, the Trench-royall and her Hand-maid Brookes: and forceth them seaven foote in height.

Six-score Acres may be drownd in three houres.

The advantage wherof, drowneth sixescore Acres in three houres, and twenty Acres in the returne backe.

In a Counter-trench forty Acres; in a Traversin-Trench twenty more; in Sommer and Winter-Trenches, twenty; in double and treble Trenches (and the rest) twenty more. 


\section{WATER-WORKES.}

Take upp the Sluce which commaunds the Stanke-royall, and in one houre, my Ever-lasting Trench conveyes the Trenchroyll and all the hand-maid Brookes, into the maine River: and (for ought I have heard) after I gave it passe, it had peaceable progres into Severne without examination.

I will acquaint you with a manner of drowning which you may very well like off.

If you will handle two or three hundred Acres of Ground you shall dayly drowne Winter and Sommer for ever, some part shelving or descending and the rest Flat-bottome, devides by DefendingTrenches: For, cleare Water will supple your Shelving-Ground if it continue thereon sixe or seaven dayes; But, ther's a discretion to bee used; Therefore I advise, as you drowne the Shelving-Ground with cold and cleare Water in the cold of Winter, suffer none to fall into the Flat-bottome; but, your Muddy-flouds: For you well know, that the water passing downeward, doth indure most violent labour in running : and beeing sodainly taken away, it doth sodainly drye, and 
The Rush will be raised by overmuch moisture.

\section{WATER-WORKES.}

none at all remaines to infect the ground.

If it steale into the Flatt-bottome, the coldnesse of the cleare-water with the coldnesse of the ground, in the cold of Winter, wanting the heat of the Sunne to dry it up (it being lodged in so plaine and pleasing a place) will venture life to raise the rush.

Now, seeing I have spoken of the excellency of drowning, I will speak somwhat of mine ambition therein.

THer was never General of an Armyroyall, nor Admirall of an Armado, more ambitious, then I have beene in braving my Trench-Royall: And wearied with over-walking my selfe therein, I repayred to my stank-royall; and I beeing raised seaven foote in height, I was so possest with the pride of my walke, that I thought my selfe fitter to bee Governour of a Towne of Warre, then Commaunder of a hungry Water-worke.

But remembring (within the compasse of my age) a Greate Person stood to bee Generall of an Armie, that never saw 


\section{WATER-WORKES.}

the face of the Warre nor never fought Combat with an Enemy; A Councell of Warr beeing called, it was answered, by a Grand-Captaine, hee had neither the Words, nor Art of War: Therefore dangerous for the State to adventure the Kingdome to try his experience: The rest more under-valued him, Saying hee were fitter to bee Chauncellor to a LordBishoppe then Generall of an ArmieRoyall.

These their censures, fortified mee in mine old labours : So by little and little, I forgatt the Ambitious Resolutions of the Honourable Warrs, and the Pleasures of a Parke (withall) wherin I yearely killed at least twenty Buckes and Sores.

The love of my Water-workes, stole my desire from thence, that in the whole number of twenty yeares, I cannot say I was at the killing of one Bucke, although my Parke-pale came within twenty foote of my trench-Royall, having some yeares twenty Buckes, killed with a kennell of Hounds, and loving the sport as much as he that lov'd it most.

The Maister of a Water-worke may well bee compared to the generall of an

Sharp censures made me fal blountly to my workes. 
A maister of a water-work compared to the generall of an army.

\section{WATER-WORKES.}

Armie, which having beleagred a Torone, it behooveth him for their safetie to fortifie and block all passages and In-rodes, that the Enemies sodaine Alarum annoy them not: So, must the Maister of a Water-worke attend every shutt, and shower that threatens excesse (whether in midday, or mid-night) commanding his Centinell-Servant to search the sluces, whether they bee up or downe.

If it happen before mowing, or in your after-math-time, take up the Sluce, and give it passage into the maine River: for, the sodaine over-plus, your Trench-royall, will convoy into your everlasting-trench; unlesse, your desire be to over-flow some parcell of pasture or meade thats overeaten.

I protest it hath beene more grievous to mee in Summer-season, to see a muddyfloud run idle with-out command, then to see a lustie wanderer quarter the country, with-out being put to worke. Touching

The severall offices of the sluces. the offices of my number of sluces; the first commands the main-river in the beginning of my Trench-royall. The second, commands the maine $R$ iver into my braving-trench some halfe mile lower. The 


\section{WATER-WORKES.}

third, commands the same River a mile below, at the lowest part of my ground: So, you see, that within the running of two miles, I plant three sluces; the maine Silles being forty foote long. The reason why I planted so many within the length of two miles, was this: the river being thirty foote broad, and ten-foote deepe, my Trench-royall beeing but ten-foote broad, and foure-foote deepe, it received no more water then the breadth and depth would give leave.

Not-with-standing the quantity of water my Trench-royall received, I did not find the want of any in the maine-river; which caused me to raise those two other sluces: grieving so commodious an Element, so rich and substantiall, should fall into the Bowels of the sea, with-out profit. I call that a Trench-royall, where part of the maine-river is commanded by sluce into it. I call that a counter-trench, where part of the river is stolne in by the rising of the flood to the levell of the banke with-out sluce. My topping or braving-trench is that which hand-maides the maine-river (side by side) unto the end of the worke. The

What a trench royall is.

What a counter trench is.

What a topping and braving trench is. Winter and Summer-trenches, bee those that 
What

the winter

and summer trench is.
What double and treble trenches require.

\section{WATER-WORKES.}

water the grounds in the Summer-time. Having drownd with cleare water a parcell of ground, it being satisfied and forsaken, I furnish the rest of my Trenches with that water, untill a Meade of thirty or fortye Acres bee sufficiently seasoned. You must know, you cannot drowne so many Acres, not having the advantage of these many Trenches and Lists, unlesse your ground bee all flatt-bottom; having a stoute and strong water with-all. My double and treble-trenches, require a parcell of plaine ground containing fortye Acres or more. At your turning-water in, it will hardlye dispeirce over the whole; the weakenesse thereof is such in Summer-season if it bee not holpe and assisted with Summer-lysts, that runne the length of the land you labour in. You may raise the Liste in this manner; In the middest of the Meade, in place of best advantage, force a couple of Furrowes of each side with your Plowe, encountring each other; cleanse those Furrowes, and place the earth above : by this meanes your List falls out to be a foote-path, when both sides of your ground are drownde, Summer and Winter.

This manner of speaking may seeme I I 6 
strange unto you; But, if you did see the manner of the worke, you would say it could not bee otherwise exprest.

The traversing-trench, is, that which receives the water from the counter-trench; and the Stanke-royall(running on a whorle, his sluce being taken up) is received by a Bastard-sluce, which doth disperse on both sides the Trenche; and that's the cause I call it a Traversing-trench.

My everlasting-trench endures more trouble then all the rest: the Trenchroyall running at a floud-time (as a shipp under-saile, beeing Admirall of the rest) and having determined of all the duties of the severall Stankes, Trenches, and handmaide brookes, they humble them-selves to the Stanke-royall; and prayes no longer continuance there, then they proove profitable to that place: which is so long as they carry filth in theirfore-heads, (I meane a muddy floud) and declining to a cleere water, the everlasting-trenche receives it to his common course, with as much joye to the Maister as may bee.

I cannot well give significant names to all those Trenches, which I call troublesome; therefore I pray I may bee forI I 7

What the everlastingtrench doth. 


\section{WATER-WORKES.}

borne to speake of them at this time. I had almost forgotten to make a true report of the everlasting-trench : it's but a bastard brooke, falling from my Parke into the mouth of my trench-royall, and his course stopt by a Weare or sluce, not inferiour to any in the maine-river. This bastard-brooke is commanded by that sluce to attend the trench-royall to the rendezvous, or place of imployment, drowning altogether, which descending against the stanke-royall, is forced into his ever-lastingcourse againe.

Against another Weare or sluce (comparable to any of the rest what-so-ever) you shall understand why these two maine

Wherefore the Weares or sluces are planted.
Weares or sluces bee planted upon so beggerly a brooke: the trench-royall crossing the brooke so farre as the ground extends, must either have passe in the end (which cannot bee with-out leave of the inhabitant belowe) or forc'd backe againe over the first Weare, three mile above; which may bee: but the purpose is, the everlasting-trench shall have an everlasting continuance, to receive the Surplus of the floud-water for defence of your Hey, and after-math. The ancient bredth and depth I 18 is 


\section{W ATER-WORKES.}

is inlarged: for, that the floud being drawne into the Trench-royall, must fall into this everlasting-trench: and being inlarged, the trench-royall intertaines it without prejudice to any of the grounds.

My lasting discourse hath almost done with my everlasting-trench. As the trenchroyall commands the everlasting-trench to the rendezvous or Consultation-place: so the counter-trench hath the like command else-where. And as the everlasting-trench is sluced to give passe to the trench-royal to the lowest part, so I place one other Bastard sluce more; which receives the counter-trench; and many times, both royall and counter-trenches meete against that sluce; which to his power, doth yeeld as much profit as any in all my workes.

If your grounds, at any time, be so hard frozen, as the hardnesse thereof is like to continue, such a snow may happen upon your frozen grounds, as may remaine thereon so long as the extremity of wether indures: or so long as you and your cattell will be weary off, which to prevent, let downe your sluces, drowne the frozen grounds when the snow begins to fall: so

What is to be done in hard Frosts, and great snowes. 


\section{WATER-WORKES.}

shall you release the grasse being bound, and spend the snowe, which threatens your prejudice, and free your grounds, that all kinde of cattle, (Sheepe especially) may have sufficient sustenance therein.

My trench royall, from the beginning to the end, is three miles long; it runnes so precisely on the plimme or levell that every fifth yeare I am driven to cleanse the channell: such store of muddy-substance is forc'd by my first sluce therein. As the River Nilus drownes Agipt from the Abissine Mountaines, enriching the countrey, to the wonder of the world : so doth the muddy-flouds from the upper part of the Golden Valley, (as from a Golden Mountaine or Fountaine) improove my estate beyond beleefe. It's not unknowne to my neighbourhood mydemeasnes at Nerv-court was set and forsaken at forty pound by year, besides my Parke, I set it so my selfe, \& let any man, that hath an upright judgment and equall eyes in his head, view and review it, hee will say it will yeeld within three yeares, three hundreth pounds yearely, besides my Parke. Many have said to me, no other mans grounds lie so convenient to drowne 


\section{WATER-WORKES.}

as mine at Nerw-court. I answred them, yes: for, three other livings of mine, affoord the like advantage for drowning. The Vale is but seaven mile in length, and not a mile over any where. Yet there be diverse Gentlemen therein, whose livings might bee bettered, some a hundred, some two hundred pounds yearly : amongst the rest, there's one that dwells on my right hand: the River devides our demeasnes, who might stock his grounds with stankes, trenches, lists, bastard-sluces, and such inventions as the ground requires; being all flat-bottom: and I truly take it, he may drowne foure hundred Acres with lesse charge tenn times then mine: not having one MaineWeare or Sluce to rayse: For, those I have planted, serves for both grounds: but whether it be his ignorance in not understanding, or negligence in forbearing, I know not; but, I am sure, it's out of his way an hundred pounds a yeare.

There is another Gentleman, who dwells on my left hand, makes shew of understanding it; yet are his grounds over-howed with the like neglect: but

The Golden

Valley is but seaven miles in length, and one mile broad. 
A liberall offer refused, which if taken, had benefited the offerer more then the offered.

\section{WATER-WORKES.}

seeming to excuse it by some unexpected troubles (which indeed hee indured) \& that his weighty occasions would not give him leave to under-take, nor suffer his servants to attend it, hee having in the eye of his house, a hundred Acres of errable land, worth not above three shillings an Acre, which amounts but to fifteene pound a yeare. Yet I made him this offer, if he would bee pleased to make it plaine, as plaine might bee, for foure yeares, I would give him fifteene pound a yeare, beeing the true valew of his land: and after the end of the foure yeares, I would take it for one and twenty, yeelding him a hundred pounds a yeare, the charge wholy mine, in raising sluces, stankes, trenches, and what else so-ever : so, during the foure yeares, hee should receive fifteene pound a yeare ; and ever after, a hundred pound yearely to him and his heires for ever.

I did not require any thing untill the foure yeares were expired, and then my demaund was but three hundred pound.

The yeare following, one hundred came in unto him againe, the second, an other hundred, $\&$ the third he received another; 


\section{WATER-WORKES.}

so in 3 . yeares, he received his three hundred pound.

He offered me nothing, and hee hath done nothing; so this is but an accusation for negligence, setting it forth in as friendly manner as I may. $\mathrm{O}$ ! if the Lord of a Mannor did but know what an offence it is to plant an under-shot-mil upon a River, where the scituation of the soile affords drownings: He were better to put his wits aworke to make Windmils in plain ground, if hee would consider what hee looseth by it.

For example ; my right-hand-neighbour having such a Mill as I speake off, worth some tenne pound by yeare, and four hundred Acres of excellent ground to handle: hee forbeares his Winter and Sommer drowning, to give satisfaction to this unsatisfiable glutton the Under-shotmil, where, in the trunesse of husbandry, hee should dayly drowne three hundred Acres for ever.

As the Sun shines ever once a day in Alexandria, by reason whereof the Land yeelds sweete increase; so might he say he dwelt daily in the Land of Canaan, which ever flowes with Milke and Hony. 
The length of the Trench Royall.
The breadth and depth of the Trenchroyall.

\section{WATER-WORKES.}

And as the greatnesse of the Turke obscures the Persian-glory, or as the Hungarian forces are the only Obstacle, hindering the Turkes descending to the conquest of the Christian Kingdomes; so should his stankes or Damms incounter the downefall of the Muddy-flouds from the Mountaines of great Cadwalleder.

Thus much to incourage my neighbour for the undertaking of Water-workes.

My Trench-royall beeing three miles long, and running plimm or level forward and backward; I plant divers Bastardsluces crosse the Trench-royall, for Winter and Sommer drowning.

If any man will bee so phantasticall as to carry his wife levell by water to her Dairy, or build Barnes and Cattell-houses over the same for ease of his Oxen, I refer my selfe to his consideration whether it be not possible; the Trench-royall beeing tenne foote broad, and foure foote deepe. Likewise if by Boate you will carry Compost, Corne, Hey, Wood, Stone, Milke, or any other, Provision, its referred to your like consideration. I made two litle Ones for the carriage of earth, which I found to doe mee such service, as I know two

Teames 


\section{WATER-WORKES.}

Teames in a day could not countervaile any of them.

Their burden beeing but two load a peece three servants commaunded them both, in ; their charging and discharging : their length being twenty foot ; the breadth but three: Had I a Boate with a Keele five or six \& thirty foot long, and nine foot broad, I would carry seaven or eight load of Compost at a time ; Corne in Sheaveswould conveniently bee carried; but how many load of Hay, at a time, I can but gesse: You must at al times examine how your Trench royall is stored with muddy-substance; it beeing furnished by the main River, every flood, every second, or third yeare it riseth in the bottom 2. foot at the least; especially for a mile or two comming in at the mouth of the Trench, it doth fil the fore-part of the same : \& unles you cleanse those parts you cannot receive so much water by 10 . foot broad, and 2 . foot deepe : the want whereof you shall find in your lower grounds. As the finest husband-men be most provident and studious to make their profit answer their labor; so let not the charge of clensing the Trench-royall be

The good service of a Boat. 


\section{WATER-WORKES.}

greevous unto you : in respect the recompence shall (much more then the greatest usury) outgo your laying out.

In the yeare I60I. I was forced to cleanse my trench-royall, being almost fil'd to the levill of the Banke, and for the excellency of the substance therein conteyned, all the dung-hils in the countrey can witnesse it was their very quintessence: the quantity thereof may be estimated by the breadth and depth; and I know five hundred honest Yeomen, Husbandmen, and Laborers would say, the Substance would over-countervaile the charge beeing imployed for Wheat, Onyons, Cabiges, Carets, or any other Rootes agreeing with the nature of that Residence of the Trenches.

Which Muddy substance beeing put on the one side of your Trench-royall, you may by Boat, carry to your wheat-land, to your Garden, or to better any other barren ground that yeeldes no profit: For, I will drowne Winter and Sommer at my pleasure, a thousand Acres of Medow.

I will sustaine no inconvenience at any time, unlesse the negligence of my servants suffer the Sluces to be upp when I 26

they 


\section{WATER-WORKES.}

they should be downe; or some envious, lewd, or malitious person, in the nighttime loose them downe of purpose to harme me.

No Subject in the Kingdome can certainly say hee hath the like Groundes, unlesse he daily drowne as I doe. And for these thousand Acres I shall bee able to Mowe them twice a yeare.

If I please: The rush, the Mosse, the boult, the hard head, and many other unprofitable wedes craves mercy at my handes for their life in respect of their former offences; with protestation never to trouble the ground againe.

I doe not see why the corvslip should have more favour then the rest, unlesse it bee to countenance the May-pole.

I have not done all I can doe, I can Graze my mowing Meades, untill the first of Maie. I would see who can doe the like, without the hazard of his Hay that Sommer, unlesse hee follow my example. It may bee sayd by some among them-selves that you (neighbour) and I, may doe the like: But then, that You, and I must live by the Rivers of Leadon, Dowbanke, Frommey, or in the Land of Lombardy, 
In Lumbardy grasse growes apparantly twice a day being cut twice a day.

\section{WATER-WORKES.}

Lombardy, where grasse groweth apparantly twice a day.

Those young Gentlemen that have scarce living ynough to maintaine themselves in the misery of this Age; should (if they did well) learne to levell and quarter a ground: then sell that little they have ; and afterwards examine the Records in the custody of the Clarke of the Statutes; there shall they finde that Clarke to have more Clyents (in my conscience) then any Councellor in the Kingdome.

And for mine owne part (without vaine-glory bee it said) I am as well knowne in that Office as a better man.

Thus, by taking paines, following the Ordinaries, and being acquainted with the Under-Sheriffs, \& Atourneies of every County; those Gentlemen for a quart of Canauary-Wine, wil give you a Kallender (a) Yronice. of all (a) the Land-lords, that are beforehand with the World: In which if they deale not injuriously with you, you shal find my name. This done, examine the Rivers', Brookes, Fountaines and Springs in every County, whether they bee imployed or no. If they run idle, make your match 


\section{WATER-WORKES.}

in the countrey you best like off; \& I assure you, you shall find more Land to be sold utterly neglected (while the water runnes at wast) then a thousand such young Gentlemen I speake off, will buy.

I do advise all men that wil be Undertakers in this Husbandry, to bee perfect in the true Survey of the number of Acres that may be drowned; and that they make choyce (as neare as they can) of errable land: which commonly exceedes not two or three shillinges an Acre yearly. Old Pasture covered with mosse, that nature hath forsaken, and Medow-ground (if there bee any) that takes more pride in the company of the Corslipp, then the gilt-cupp which carrieth the garland from the rest.

And for your comfort, (bee this spoken) if in the laying out of five hundred pound, at the end of foure yeares, you make it not two or three thousand pound, your Nota.

choyce is bad, and lucke worse. During those forty yeares you cannot receive lesse then the rate you buy it att; which is twenty yeares purchase, or as you can agree : And so from five hundred to a thousand, two, three, or as much as your estate will stretch too; the more the better.

I 29 


\section{WATER-WORKES.}

If you finde difficulty in my discourse; any Easter or Michell-masse Tearme you shall finde me in the house of a true Brittaine (maister Wotton a Scrivener) in Fleet-street, over against Saint Dunstans Church. And for a Supper, at Fohn Gents you shall have your Belly-full of Water-workes. For my Drownings, my name hath beene so scandalliz'd in open Ordinary, by a Westerne Gentleman, who, since the Kings Majesties comming, is become a Knight of account, but rash censure deserves little reckoning in mine account: Many men spake diversly of my labours for a long time, because the Honourable Courts (as they thought) had brought mee to Beggers-bay: and failing in the true execution of my workes, in not placing a Planke of foure inches thicke, and twenty inches broad, under the maine Syll, to prevent the water from undermining the same, and withall fayling to lay my Groundes (by the indiscretion of my Servants) levell or plaine, and not understanding of what strength my Stanks should be to with-stand the weight of the Water that playes against them, $\&$ what alowance to give each Stanke in 


\section{WATER-WORKES.}

his Foundation ; and forbearing the running of my Trench-Royal to the end of his Course for many yeares, and not thinking Stankes to bee necessary for the commaunding of Grounds disoebeying my desire, and withall (lately) running Counter-Trenches, which next the Trench-royall, have place above any; which were not drempt off before; many sluces, and for many yeares, were forborne in places most convenient, and much profit lost thereby: my speculation having continuance in practise above twenty yeares.

But were it now to beginne againe, I would performe it in one : and raise it to the greatest profit in foure : so hard a thing is it for any mortall man to perfitt any profitable invention, without paines, cost, and continuance of time.

They say now, if Maister Vaughan had these \& these grounds he would doe This and This. This opinion have I gotten in the countrey where I dwell.

There is a Shropshire Gentleman(Maister Hoord) a famous man, his labours (I know) have taken tryall at Envies Barre, by ignorant Furors and unjust Fudges for a worke hee performed. It was chargeable unto I 3 I

Twenty

yeares practise in these Workes. 


\section{W ATER-WORKES.}

him ; the situation thereof was such as it could not be otherwise handled. I saw it, viewed it, and examined it; and I know it doth much more then countervaile the charge. But had I beene acquainted with him, in his first beginning, he should not have spent his time to so small profit: not that he mistooke in the handling therof; but knowing my owne errors, and by costly experience able to instruct him; I found no want of Arte in him, but the want of Winter and Summer-water to serve his turne.

I would have perswaded him to have forborn that barren under-taking, \& to have gotten five or sixe thousand pound with ten times lesse labour, in the choice of a thousand places elsewhere, where hee might have drowned dayly for ever.

Muddy

flouds often happen in Summertime.
Muddy-flouds doe often happen in Summer-time. If the running of them idle bee so unto other men as it is unto mee, let them doe as I doe; ever have one pasture bare eaten: and as you keepe one speciall Chamber in your house to entertaine a stranger, so, you alwayes have one Pasture for that muddy-floud, which will pay you after twice twenty in the hundred. 


\section{WATER-WORKES.}

hundred. It's confessed by all in the Golden-Vale, that that little land which wee have would be bettred fifteene hundred pounds a yeare. If the like were done through-out England, it would profit the kingdome in a yeare two Millions: which would maintaine an army-royall, to the honour of Great Brittaine, and be most comfortable to all honourable Souldiers, Crest-falne for want of warre and military imployment.

It pleased maister Hoord to view the place where my Water-workes were performed, accompanied with three juditious and understanding Gentlemen, namely, Maister Brainton, Maister Pearle, and Maister Wolridge; what their beleefe was, I referre it to those who have a desire to be informed.

Any Gentleman or other having performed a worke, and brought it to his absolute perfection; should not sit downe by it: but having finished that Worke, and being Maister but of one Living, I would (as I formerly said) advise him to sell it: and at the end of foure yeares make good account by purchase, to gaine sixe, if not ten for one. I have a Meade

Note this advice.

Note the profit of drownings. 


\section{WATER-WORKES.}

called nine dayes-math: an excellent Meade, and approved for such of all my neighbours. I sold the herbage thereof diverse yeares for five pound per Annum: but within few yeares, after the flouds plaid upon it, I solde the Hey for ten pound yearely : and the latter or aftermath was richly worth five. I will graze this Meade untill May: yet notwithstanding the Hey will yeeld me ten pound, and the after-math five. Now having (I hope) profited the intelligent Reader, thus far: al the favour I desire at his hands, in lue therof, is this, That I may have leave to give new names unto mine old grounds, without beeing laught at in ordinaries by scarce ordinary understanders. Some they must have; for, those they had by drowning are covered with new earth. And with-all, they bee inlarged above two hundred Acres. I cannot call that the nine-daiesmath, which now is above 30. (unlesse I should forget my counting-craft) nor that a Moore which is firme and pleasing ground; nor that the rushy-leasow, which is reduc'd now unto a more fruitfull and profitable plot, if the rush appeare there 


\section{WATER-WORKES.}

againe, he forfeits the Fee-simple of his life: so having my grounds devided into I 2. parts, their names (under favour) be altered and now called in this manner: the Pinck, the Gille-flower, the Carnation, the Rosemary, the Mary-gold, the gilt-cup, the Honysuckle, the Daysy, the Garland, the Eglentine, the Corvslip \& the Primrose. Some do say their Kine doe yeeld more milke having often change, then those that graze in only one pasture. I say nothing to it: but, beleeve those dairy women that affirme it. This I can say, for any that desire often change, (as the most part would have fresh and fresh pasture) if they (being curious) will not bee coy to handle a Cow-shore in his kinde: then thus; When the Kine bee put over to some other ground, you know their staine or dung by heate of the sunne will grow hard: and within short time, will force a proud and insolent grasse; such as the Kine in their returne will not touch.

When you turne out your Kine into fresh feeding; bee sure to disperce and sever those Cow-shares, that the place be not stained with any polution. They

The new names of the Meades and Pastures. 


\section{WATER-WOR KES.}

being dispersed; drowne your ground with cleare water : or mudd (if a floud happen) the ground being bare, two Blessings incounter each other, and purifie the place where the Cow-shores were falne : so, at the next turning in of your Kine, some fortnight after, they shall finde nothing to distemper or offend the taste : the water doth cleanse and cleare all annoyance to the beast, and breeds perfect life in every growing grasse. This last Summer I604. in Trinity terme, being above at London, I came not downe till after Mid-summer: having grazed my mowing Meades too too long after May. Upon my returne, I enquired in what state my grounds stood, my servants answered they were sufficientlye seasoned;

Eye-pleasers are often liers. but (in deed) they did (as many servants doe) report the best of the worst, to excuse their negligence : the Meades were not so sufficiently drownd, as the necessitie thereof required: They being neglected before mowing, not trying their temper with a riding-rod, (my beliefe was so great in those greater Liers) but after mowing, the truth appeared, the quantity of Meade (in one place) being three score I 36 and 


\section{WATER-WORKES.}

and ten Acres, by reason of the mowing, making, and cariage, before the ground were free to drowne, the extremitie of the heate was so great, that the grasse turned yellow; being tainted, as a sheepe on a drye rotte: or, as a man inlye sick, and newly recovered faules into a relaps againe.

In this manner my grounds had gotten the greene-sicknesse or a burning-feaver (I know not well whether) If in the extreame heate you would drowne with Judgement, you should not drowne in the heate of the day: but in the night from sunne to sunne. But being forc'd, I suffered the water to worke night and day ; the season of the yeare falling out to bee dry: the sunne extreamly hotte; the ground hott, dry, and hard: so what betweene the heate of the sunne, and heate of the ground, the water became luke-warme, and faild to effect that good which by Nature other-wise it would have done.

And if I be not deceived, the infection of the earth, had poysoned the water: or made it so sick, as it was not able to endure the ground. As a scudding shewer

$\mathrm{K}$ 


\section{WATER-WORKES.}

The quality of raine, doth raise upon a dung-hill-poole of ground distempered with heate. great bubbles (like an Oxe-eye) by falling of the drops thereon; or, as water in a pott, by the heate of the fire, doth labour, and shew distemper: so, did that waterworke, play, and bubble on the face of the ground, shewing (for a quarter of an houre) nothing but discontent.

The ground being qualified, the grasse did not instantly grow (as at other times, being orderly fedd) the coullour being changed, the grasse standing at the point of death, being in that case as a sicke pacient having taken a purgation, who must have a time of recovery: so did the grasse, for diverse dayes, shew nothing but sorrow, heavinesse and all discomfort. It beeing once made yellow by the heate of the Sunne, and recovered of the rellowFaundies, although the comfort of the water put life into it; yet, during the season, it had never his perfect complection againe: the point ever carrying a shew of poysoning; which error (with Gods helpe) I will never committ hereafter.

Let all men drowne before they Mowe, and after Mowing, your grasse will not bee yellow, but as greene as a Leeke. 


\section{WATER-WORKES.}

You must alwayes keepe your grounds in a true temper; they must never be too wet in the Winter, but when you drowne; nor too drye in the Summer, having water enough. I had almost forgotten this; before you raise your stankes, bee sure to cleare your grounds from Moles or Wantes, they bee dangerous creatures (like a Usurer that's hardly gotten out of a mans land, wherein hee hath gotten footing, if they have possession in a stanke.

You know when all other grounds be drownd some part of the stanke will bee free; they will not faile to rend and teare your stanke like Rabbets in a sandy soile. I protest two or three Wants in my stanke-royall, was out of my waye twenty pound a yeare, for many yeares. I put a fumbling fellowe to attend their walkes, who (not beeing cunning enough to destroy them) utterly plagued me; until I hapned upon a good worke-man, who hath cleared my stankes \& my braving-trench. And were it not for my braving-trench and my stankes, I should never need the use of a Want-killer; because I do so oft drowne in Winter-

Moles are mischievous vermin in or about such water-works. 


\section{WATER-WORKES.}

time; which often drowning doth force them to forsake the soile.

I would desire no better pastime then the hunting of a Wante in a plaine Meade. My braving-trench being close by the maine River: my trench-royall lying on the height of the ground: my servant seeing her cast, if neare the trench-royall hee commands water into a descending trench; and doth force her on the face of the ground with much submission, praying her Clergie: her offence being Burglary in breaking my stankes, although she were the first meanes that occasioned all these under-takings, yet I could not bee drawne to yeeld her a pardon: had she wrought in any other part of my grounds, I had not taken it so grievously: but, in spoyling my fundamentall parts, with working cleane through my stankes, and forcing them, by the extremitie of the water altogether doune, she was uncapable of pardon. If he that hath an over-shoote-Mill would enter into an account with him-selfe, whether it were more profitable for him Winter and Summer to drowne grounds, or to grind corne, it would put him to a pussle. 


\section{WATER-WORKES.}

I know many men that have Mills, who for a desire to gaine a peck of corne a daye (and many dayes failes to get any) so that by a true computation, in the whole yeare, the Mill may bee worth some foure or five pound: and in drowning, foure or five acres of barren ground,

Drowning more profitable then Mills.

I will raise a farre greater benefitt.

But because he wil give reputation unto his demeasnes, or information on the marriage of his sonne, that hee hath such a Mill; hee had rather suffer muddy Flouds in the Winter, and cleare Waters in Sommer to breake their limbs on his Mill wheeles, then exercise his wits (by Drowning) to attaine a world of wealth.

It is grone to a kinde of proverbiall speech, in the Golden-Vaile, that hee that doth drowne is a good Husband: hee that may and wil not, is figured out with the sillable, Fu.

I know, I have as good an Over-shotmill for Water ynough as this Kingdome yeeldes: yet rather then I would grinde my owne Corne at a floud-time, or in my drowning times in Sommer, I would carry it tenne mile off to be ground, though the Miller told the one halfe.

Beeing 
Drayning of Grounds, cousineGermain to Drowning.

\section{W A TER-W O R KES.}

Beeing requested by many Gentlemen of the best quality, to putt these Waterworkes in Print: I praied those ingenious Gentlemen, (Sergeant Lovell and maister Coulthurst) to speake what they thought concerning the same.

They both (under their handes by way of subscription) said ; it would bee very profitable to the Kingdome to be put in execution : being of late a common thing in Devonshire; but, not in so ample manner.

For drayning of groundes Maister Levell is Serjeant-Major of the same; yet Ile say as the meane Counsellor saith to the Serjeant at Law; under favour (maister Serjeant) Ile declare what I didde in your Element of Drayning, beeing but Cousin-Germaine removed to mine of Drowning.

A Ring of ground (some foure-score Acres) scituate stirrope-wise; a Brook in the upper-part crossing the same, in the smaller point of his extent, there running from Adams dayes in likely-hood: the greater quantity of the ground from the Creation never found : but stain'd with the Boult, the Rush, a 2uagmire coherent, with many other Improfitables never mowed, 


\section{WATER-WORKES.}

mowed, nor grazed in the driest daies, but knee deepe in water. It lay at the gaze for five thousand six-hundred and six yeares, and by general opinion it stood in state of damnation; as if it hadde beene curs'd like Mare-mortuum for the sin of Sodom.

When I hadde devided my sounde Groundes from those infected with leprosie; with as many maister-trenches as were needful to conduct my Drayning, Sucking, Working, \& Searching-trenches into the maister-trenches; having but two foote descent to procure a passage; all this beeing performed; that spungy bogg draind, dryed and made fitt for any use : I drew the Brooke which crossed the upper point of the-Ground downe into the belly of the bogg, to make privy search in every particuler Trench, what filth fell therein.

Livery and Season taken, Atornement of Tennants, Fealty, with all other Ceremonies that Littelton layes downe to raise

Livery \& Season taken by the Brooke.

Uses, Customes, or Estates of Inheritance, with payment of pence, and the strongest Fortifications my skill could afford for an everlasting continuance, and cleare keep- 
A necessary Invention for suppling hard Groundes for easinesse of Trenching.
Countrymens Conjectures ar not alwaies Oraclces.
WATER-WORKES.

ing of the Drayning, Sucking, Working, and searching Trenches.

I protest I had almost forgotten this insuing most necessary Invention.

I was in the Parish of Peter-Church to runne a Trench-royall some mile on the plimm : The Countrey-people made themselves beleeve it would cost mee a thousand Markes. Before I ran any part of my Trench: I planted my Sluces crosse the River, at such time as my Sluces were downe, the Water did rise to the levell of the Greene-sward: the Sluces beeing uppe, the Water suncke unto his ordinary course againe.

So hadde I the commaund of the Sluces to ryse and sinke the Water at my pleasure.

Having levelled the Trench: I put eight Labourers to worke therein, who, (during the whole day) wrought but one Pearch, which was but sixe foote broad, and three foote deep: To whome I said (when I perceived how little they had done in a day) I see now it's true, as the Country saith: It will cost me a thousand Markes ere I effect this Worke, if it go no better forward. They said unto 


\section{WATER-WORKES.}

me they did their best indeavor: But after they had taken some halfe a foot of the greene sward (or face of the ground away) they could not force their spades or spittels one inch deepe, the hardnesse of the Earth was such : and wish'd mee to give over that under-taking.

It was some-what before Michelmas (the Winter-raine not having suppled or mollified the ground any whit at al) I commanded them to attend their labour on the morrow; then did I cause them to run forty pearches in length, six foot broad, \& but halfe a foot deepe ; which halfe-foote deepe the spades did easily enter : And so for that day, I ended with them. Then they demaunded what imployment I would putt them to the next morrow? I bad them good night : and willed them to bee there very early in the morning. After they were gone I caus'd my man, to let downe the sluces, and raise the Water to the height thereof, and Sodainly the Trench flowing, it entred with such puissance as if it would have dissolved the very Bowels of the Ground. Then early before their comming my Servant tooke up the Sluces, sunke 


\section{WATER-WORKES.}

A notable sodaine effect of Water on hard ground uneasie to bee

Trenched.

The manner of breeding Calves. sunke the Water, and gave it the liberty of the maine River, that they the next day, easily forced their spades two foote deepe and more. And in this manner, with the water, I suppled the Trench from the beginning to the end, \& saved therby a hundred pound at least.

Many worthy and expert men have written of the breeding of Cattell, whose indeavours I much reverence, and referre them to bee commended by Posterity : Yet, will I venter to lay downe mine experience in the younger sort, for the Falling, Weaning, and Raising of Calves: which (breefly) is this: Those Calves you meane to breed: a month before they fall, lett your Cow or Kine bee well fed with good Hay, that she or they may be the better able to bee delivered of them, and to yeeld plenty of Milke: Uppon their first Calving, suffer them not to have too much milke for three or foure dayes: For in over-sucking them-selves, they will bee so glutted with the plenty and newnesse of it, that nature in them will bee overcome, $\&$ be subject to Gillying or Scowring, which wil hinder them for a long time. When they bee five or sixe dayes 


\section{WATER-WORKES.}

old, let them sucke as much as they can: When they come to bee a month old, provide a Cratch for fine Hay, and a Trough for cleane Water, although you have no meaning that they shall sustaine them-selves thereby: but to prepare and acquaint them (in a wanton manner) to learne to eate Hay, and drinke Water. Dayly they will bee nibling with the Hay and Water as desirous as some idle persons bee of Tobaco and Ale.

When they bee eight weekes old take away the Milke of one Teat from your Calfe in milking your Cow before the Calfe bee suffered to sucke: the want of which Teate (for hunger and thirst) will provoke both your Calfe to eate Hay, and drinke Water. Continue him so for foure dayes; then take away, or milke one other Teate from your Calfe as aforesaid, which is halfe the Milke; so, will you force your Calfe to a greater desire of Hay and Water: After this, take away the milk of another Teate within foure daies after; and so after that take away all. Handling the matter in this manner, your Calfe will never mourne, for want of Milke or losse of Damme, but will cheer-
How to learne them to eat Hay \& drinke Water. 
What you must do when you purpose to turne them to Grasse.

\section{WATER-WORKES.}

fully fall to eating of Hay and Drinking of water immediately.

Let your servants be very carefull to litter them with cleane Straw dayly, and keepe them sweete with good Hay : and let them never want cleare water. If you have good scope of House-roome lett them run and play their fils: When you purpose to turne them to grasse, keepe them in the House uppon Hay and Water untill Mid-may: If you turne them out (as the most do) in Aprill, you undoe them : the nights being cold, the grounds cold, the grasse weake and raw: they never acquainted with the ayre, will mislike with your unkinde dealing: in token whereof the heyre will turne; and their bellies loose, scowre, or gilly, that they never will be themselves: because the Sun hath not wrought sufficiently with heate to comfort the ground that should feed and comfort them.

When they have beene some month in your best Meads in Mid-may, and after recovered their strength : put them into some higher Groundes where there is Grasse, water, and shadow ynough : Lett them rest there untill Bartholomew: then 


\section{WA TER-WORKES.}

put them over into your After-maths before the time of the yeare growes cold, and then it wil so puffe them with pride that al the winter following they wil scorn the malice of the hardnesse of the Season if they may have their fills of Hay, and fogg with a Hovell or House in the extreamest cold daies to shelter them.

The first yeare beeing spent, every man knowes how to handle them: If you will have them principall cattell, give them hay ynough the second Winter.

But what a Calfe am I to teach Countreymen to breed Calves by Art, when they (good Husbands) breed them fast Husbandmen breeds Calves by Nature. ynough by Nature; I therefore bequeath this Doctrine to Gentlemen that can better tell how to breed a Hound then a Calve; and referre what else might be spoken, to the discretion of the experienced.

Thus have I toucht what I handle with as much brevity as I could: ommitting nothing that may give evidence on the behalfe of those Perticulers, which will fall out to bee as true in effect as in apparance when ever they are put to their strictest Triall. 
THerefore, now nothing remaines

1 more to be said; but to intreat thee (friendly Reader) to beare with my merrysorry Stile, if therin any where I have not observed a precise scholler-like Decorum: for Mars his University (wherein sometime I have bene matriculated, and proceeded to some degrees of command, according to my study and time spent therein) affoords no rules of speaking in Print, yet Soldiers (in their Element) best speake in Print: and can expresse what else lies in the compasse of their spacious conceits, like men of Wit, Arte, and Courage; which they that speake altogether by the Booke, oft faile to performe. But howsoever, as this Worke, now finished, is published for thy profit, and exprest in such manner as I thought would yeeld thee most pleasure: so thou wilt accept it kindly, and thereby give me cause to be ever studious of thy benefit.

Principally, though lastly, I am humbly to intreate you (my good Lord of Pembrooké) tolooke on my plainenesse, and winke at my boldnesse: the first, proceeding from my Nature, the last, from my Education: 


\section{W ATER-WORKES.}

Yet, what is here bluntly expressed, was first of all sharply conceived, with much whetting of Witt, and no lesse filing of Invention. But what it is, it is all Yours, as he is, that will no longer bee, then he remaines

\section{Your Lordships even} beyond his uttermost.

Rowland Vaughan. 
Those that are desirous to see a Mill sawing Timber, there shall their desires bee fully satisfied, seeing a Mill by a Water-course, keepe a dozen Sawes on worke together. As also by the like streame of water, a dozen Spitts or Broches turned at once. Which turning, turnes all Turn-spit Facks out of countenance, though they be never so sawcie, and their tongues runne on Wheeles, yet, this Water-worke, workes them out of all favour with the Cooke, that loves to doe much with little labour, whom the Facks distemper (which often happens) soone makes hott as a Tost, because (like a Cricket) he lives ever about Fyre. 


\section{The Conclusion.}

THus runnes our Water-workes unto this end,

1 That all that worke by them, by them may play:

For, if they Mossy-grounds by them amend,

For paines and pleasures (then) they'l freely pay.

This WORKE consists not (like some idle Tracts)

In shew alone, or Speculation:

No; this is practicall, faire shewes in Acts,

To make the poor'st, the richest Nation.

Then, chiefly amy'd I not at publick-good,

I would not thus divulge my private skill:

But, bee'ng free-borne, my Natur's like my Blood;

Which would do good to all, and no man ill:

Then, $A l l$ (I hope) or of that $A l l$, the best

Will wish me well : as for the rest, I rest.

Theirs as they give me cause,

Rowland Vaughan.

\section{FINIS.}

\section{In praise of the Worke and Author.}

TO praise a worke of such a worth as this,

1 That shews the way t'inrich both earth \& man:

Deserves a witt that rare and excellent is,

And all to short, excell in what it can.

The Author, and his worke do merit fame;

With-out the glory of a Poets name.

Anthony Davies.

L 
$\mathrm{B}$ Ee it knowne unto all men by these presents, that I Rowland Vaughan of New-court in the County of Hereford Esquire, do acknoweledge my selfe to orve and stand duly indebted unto

in the Countie of

40. shillings of larwfull money of England, to be paid unto the said

his heires, executors, or administrators at the full end and determination of five yeares next ensuing the date hereof. To the robich paiment well and truly to be made, I the said Rowland Vaughan, doe binde mee, mine heires, executors, and administrators, firmly by these presents. In witnesse wherof I have caused this Bill, thus in Print, to bee made as my Deed, and have here-unto set my name, the xxix. of November, in the yeare of the raigne of our soveraigne Lord James, by the grace of God, of England, France and Ireland King, defender of the Faith, the vii. and of Scotland the xliii. I609.

\section{By me Rowland Vaughan.}




RETURN TO the circulation desk of any University of California Library or to the

NORTHERN REGIONAL LIBRARY FACILITY Bldg. 400, Richmond Field Station

University of California

Richmond, CA 94804-4698

ALL BOOKS MAY BE RECALLED AFTER 7 DAYS

- 2-month loans may be renewed by calling

(510) 642-6753

- 1-year loans may be recharged by bringing books to NRLF

- Renewals and recharges may be made 4 days prior to due date.

DUE AS STAMPED BELOW

\section{SENT ON ILL}

\section{APR 072000}

U. C. BERKELEY 


\section{YC103998}

U. C. BERKELEY LIBRARIES

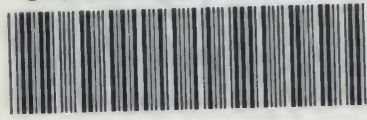

C046597500

UNIVERSITY OF CALIFORNIA LIBRARY 
